\title{
Intra-Soil Milling for Stable Evolution and High Productivity of Kastanozem Soil
}

\author{
Valery Petrovich Kalinitchenko ${ }^{1, *}{ }^{1}$, Alexey Pavlovich Glinushkin ${ }^{2}{ }^{-}$, Vladimir Konstantinovich Sharshak ${ }^{1}$, \\ Evgene Panteleimonovich Ladan ${ }^{1,+}$, Tatiana Mikhailovna Minkina ${ }^{3}{ }^{1}$, Svetlana Nikolaevna Sushkova ${ }^{3}{ }^{(0)}$, \\ Saglara Sergeevna Mandzhieva ${ }^{3}{ }^{(0}$, Abdulmalik Abdulkhamidovich Batukaev ${ }^{4}$, \\ Vladimir Vladimirovich Chernenko ${ }^{1,5}$, Ljudmila Pavlovna Ilyina ${ }^{6}$, Vladimir Mikhailovich Kosolapov ${ }^{7}$, \\ Andrei Igorevich Barbashev ${ }^{3}$ and Elena Mikhailovna Antonenko ${ }^{3}$
}

Citation: Kalinitchenko, V.P.; Glinushkin, A.P.; Sharshak, V.K.; Ladan, E.P.; Minkina, T.M.; Sushkova S.N.; Mandzhieva, S.S.; Batukaev, A.A.; Chernenko, V.V.; Ilyina, L.P.; et al. Intra-Soil Milling for Stable Evolution and High Productivity of Kastanozem Soil. Processes 2021, 9, 1302. https://doi.org/10.3390/ pr9081302

Academic Editor:

David Fernández-Calviño

Received: 31 May 2021

Accepted: 23 July 2021

Published: 28 July 2021

Publisher's Note: MDPI stays neutral with regard to jurisdictional claims in published maps and institutional affiliations.

Copyright: (c) 2021 by the authors. Licensee MDPI, Basel, Switzerland. This article is an open access article distributed under the terms and conditions of the Creative Commons Attribution (CC BY) license (https:// creativecommons.org/licenses/by/ $4.0 /)$.
1 Institute of Fertility of Soils of South Russia, 2 Krivoshlykova St., 346493 Persianovka, Russia; agronik-sharshak@yandex.ru (V.K.S.); evlad2@mail.ru (E.P.L.); tchernencko2011@yandex.ru (V.V.C.)

2 All-Russia Research Institute for Phytopathology RAS, 5 Institute St., 143050 Big Vyazyomy, Russia; glinale1@mail.ru

3 Southern Federal University, 194/1 Stachki Prosp., 344090 Rostov-on-Don, Russia; tminkina@mail.ru (T.M.M.); terra_rossa@mail.ru (S.N.S.); msaglara@mail.ru (S.S.M.); barbashev_andrei@mail.ru (A.I.B.); antonenko1102@yandex.ru (E.M.A.)

4 Chechen State University, 17 Boulevard Dudaeva Ave., 366007 Grozny, Russia; batukaevmalik@mail.ru

5 Agroconsulting Ltd., 344030 Rostov-on-Don, Russia

6 Southern Scientific Center RAS, 41 Chekhova Prosp., 344006 Rostov-on-Don, Russia; iljina@ssc-ras.ru

7 Federal Scientific Center All-Russian Williams Fodder Research Institute of the Russian Academy of Science, 141055 Lobnya, Russia; vnii.kormov@yandex.ru

* Correspondence: kalinitch@mail.ru; Tel.: +7-9185333041

+ Deceased.

Abstract: The long-term field experiment on the Kastanozem showed that the standard moldboard plowing to a depth of $22 \mathrm{~cm}$ (control), chiseling to a depth of $35 \mathrm{~cm}$, and three-tier plowing (machine type PTN-40) to a depth of $45 \mathrm{~cm}$ was incapable of providing a stable soil structure and aggregate system. The transcendental Biogeosystem Technique (BGT*) methodology for intra-soil milling of the 20-45 cm layer and the intra-soil milling PMS-70 machine were developed. The PMS-70 soil processing provided the content of $1-3 \mathrm{~mm}$ sized aggregate particle fraction in the illuvial horizon of about 50 to $60 \%$, which was 3 -fold higher compared to standard plowing systems. Soil bulk density reduced in the layer $20-40 \mathrm{~cm}$ to $1.35 \mathrm{t} \mathrm{m}^{-3}$ compared to $1.51 \mathrm{t} \mathrm{m}^{-3}$ in the control option. In the control, the rhizosphere developed only in the soil upper layer. There were 1.3 roots per $\mathrm{cm}^{2}$ in $0-20 \mathrm{~cm}$, and 0.2 roots per $\mathrm{cm}^{2}$ in $20-40 \mathrm{~cm}$. The rhizosphere spreads only through the soil crevices after chilling. After three-tier plowing (PTN-40), the rhizosphere developed better in the local comfort zones of the soil profile between soil blocks impermeable for roots. After intra-soil milling PMS-70, the rhizosphere developed uniformly in the whole soil profile: 2.2 roots per $\mathrm{cm}^{2}$ in $0-20 \mathrm{~cm}$; 1.7 roots per $\mathrm{cm}^{2}$ in $20-40 \mathrm{~cm}$. Matric water potential was higher, soil salinization was lower, and the $\mathrm{pH}$ was close to neutral. Soil organic matter (SOM) content increased to $3.3 \%$ in $0-20 \mathrm{~cm}$ and $2.1 \%$ in $20-40 \mathrm{~cm}$ compared to the control $(2.0 \%$ in the $0-20 \mathrm{~cm}$ soil layer and $1.3 \%$ in the $20-40 \mathrm{~cm}$ layer). The spring barley yield was 53\% higher compared to the control. The technology life cycle profitability was moldboard $21.5 \%$, chiseling $6.9 \%$, three-tier $15.6 \%$, and intra-soil milling $45.6 \%$. The new design of the intra-soil milling machine provides five times less traction resistance and $80 \%$ increased reliability, halving energy costs.

Keywords: Kastanozem complex; Biogeosystem Technique methodology; intra-soil milling; soil aggregate multilevel system; soil organic matter; yield efficiency 


\section{Introduction}

Soil change under different agricultural practices is a concerning issue [1,2]. This urgently requires innovations in ecosystem development [3]. The soil properties depend largely on the soil aggregate system [4]. The soil pore network provides a living space for plant roots and microbial communities to access the organic substrate, oxygen, carbon dioxide, and water for live biomass and soil organic matter (SOM) formation. There is a need for a well-developed soil pore network [5]. This is possible via optimization and stabilization of the soil geophysical dispersed aggregate system $[4,6]$. The current agriculture system adversely influences the composition of the soil aggregate system. The growth of plant and soil productivity depend on the adequate management of the soil multilevel geophysical network architecture [5]. The dynamics of the soil structural organization are an initiating factor of the soil genesis. The geophysical structure of the soil porous media changes permanently [6]. The dead-end porosity of the soil is up to 99\% [7].

Soil mechanical processing has a direct impact on soil properties. In the standard moldboard plowing system, the soil layer below the plowing depth is excessively compacted. Conditions for the SOM formation and turnover are getting worse. The SOM accumulation and transformation into the nutrients is insufficient [8]. A new soil mechanical processing concept is required to maintain the soil geophysical system properly [9].

In view of the standard moldboard plowing shortcomings, the multi-tier and chisel plowing apply for soil loosening to a depth of up to $1.8 \mathrm{~m}$. The passive working bodies of these machines divide processed soil into large blocks [10,11]. However, the soil rough block structure cannot be the goal of soil processing. The soil with a multilevel fine aggregate system is acceptable for the priority plant's root growth.

Active milling rippers (rotary tillers, rotavators) are used to obtain better soil properties [12,13]. These devices are equipped with soil mills mounted on a horizontal or a vertical shaft [14]. The general disadvantage of the soil milling machines of this type is excessive dispersion of the soil surface layer. This is dangerous in view of soil erosion, and SOM mineralization is high as well. The vertical mills compact bedrock excessively due to the reverse grinding angle of cutters.

The Kastanozem adverse property is the eluvial-illuvial differentiation of the soil profile, and the standard agricultural system of soil processing worsens this [15].

Standard regulations of the quality of soil mechanical treatment impose limitations only on the number of clods on the soil surface after tillage [16,17]. As a result, the standard tillage system deteriorates the soil texture, physical fractions differentiation, and the hierarchy of aggregation. Soil porous media geophysical hierarchy degrades [18], as well as the soil quality, functions, and conditions for the growth of the microbial community [19].

Available soil mechanical processing methods do not provide long-term stability of soil geophysical, agro-physical, and biological properties for priority-plants growth [20,21]. Modern studies show a need for an improved understanding of soil health [22,23].

On the one hand, a result of the soil mechanical processing system is to be closer to the structure and architecture of natural soil. On the other hand, the soil mechanical processing system is not to be imitative. Artificial soil structure and architecture are to be transcendental to promote a stable fertile soil evolution. Obviously, the answer is out of the narrow span of the current tillage methodology possibilities. New soil processing developments are crucial [24]. There is a need for soil mechanical processing methods to provide the soil macroaggregates and microaggregates for enriched stable biogeochemical turnover [25,26], and a multilevel heterogeneous soil architecture synthesis [27]. Preferable conditions will appear for polymicrobial biofilms and SOM synthesis and function [28].

We propose the Biogeosystem Technique (BGT*) methodology focused on the naturefriendly (but avoiding full-scale nature imitation) technical means and technology development for long-term optimization of the soil geophysical and biological properties $[29,30]$. Intra-soil milling is one of the BGT* developments. The intra-soil milling ensures the formation of fine-aggregate system in the soil's illuvial horizon. The intra-soil milling activates organic matter synthesis and reduces SOM's excessive degradation and loss from 
the soil. The BGT* methodology is a promising strategy for mitigating and even reversing soil degradation. This ensures a sustainable vector of the long-term evolution of highly fertile healthy soil [20]. The prerequisites will become better for the plants' higher resistivity to pathogens [31].

This study is devoted to the development of intra-soil milling, focusing on the synthesis of soil porous media of multilevel architecture. The intra-soil milling cutters and intra-soil milling machines were developed. A long-term intra-soil milling field experiment was fulfilled. Some data and figures from our former publications are partly repeated in the text so as to not force the reader to search the initial and intermediate data.

The research aimed for the study of the soil morphological, geophysical, chemical, physicochemical properties, SOM root development, yield, and agro-economic efficacy of the intra-soil milling of the Kastanozem complex. Based on the former research, a new-generation intra-soil milling machine with reduced traction resistance and higher reliability was developed.

\section{Materials and Methods}

\subsection{Site Description}

The object of research belongs to the dry steppe of the Rostov Region, Southern Russia (within $46.1^{\circ} \mathrm{N}-47.5^{\circ} \mathrm{N}$ and $41.7^{\circ} \mathrm{E}-44.3^{\circ} \mathrm{E}$. Figure 1). The climate of the Rostov Region is continental, arid, with annual precipitation of 300-350 $\mathrm{mm}$ [32]. The parent rocks are carbonate and carbonate-sulfate loess-like loam and clay. The landscape is plain and mainly automorphic [33].

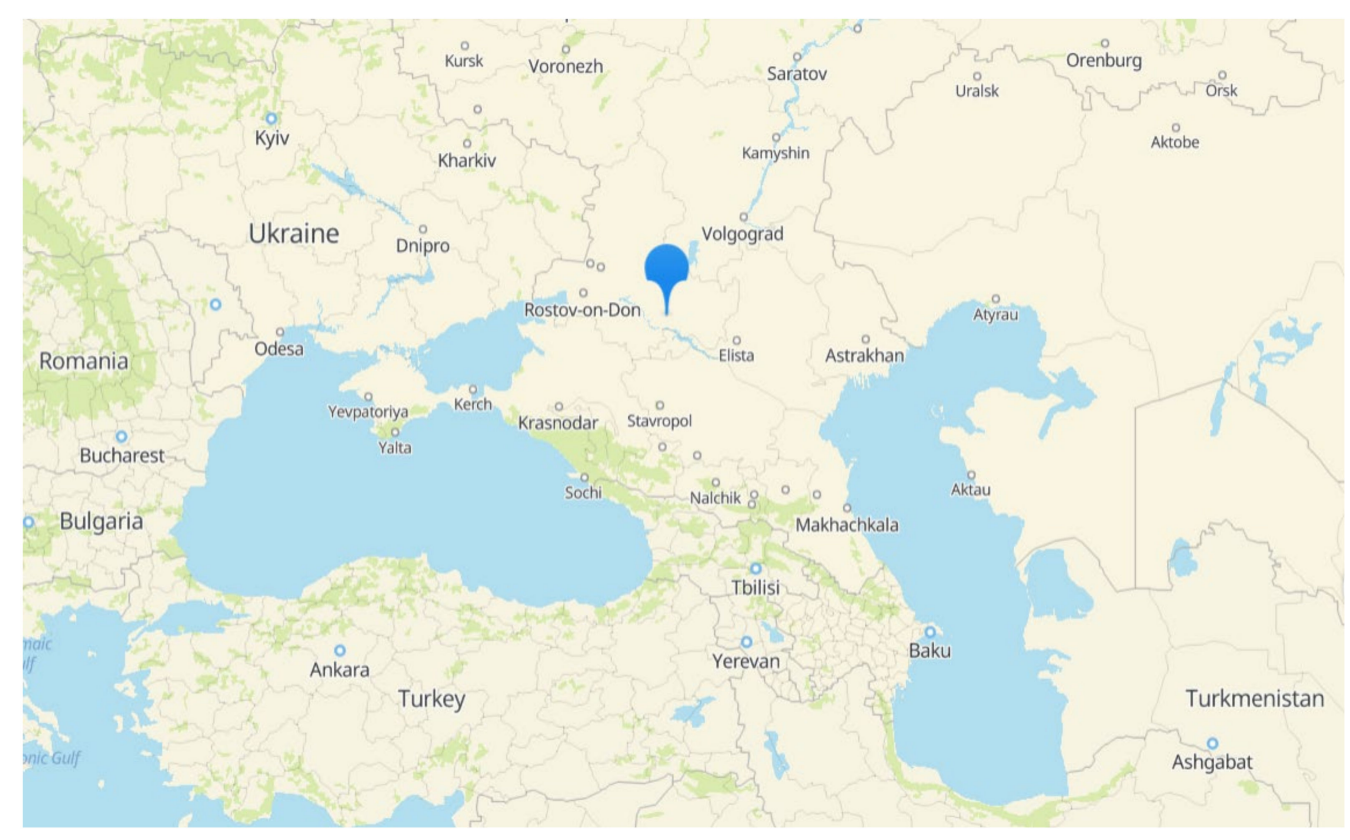

Figure 1. Kastanozem complex of the dry steppe South Russia in the Rostov Region (blue mark-the Kastanozem complex area geographical center). 2GIS. https: / /2gis.ae/geo/36.933956\%2C46.209306? $\mathrm{m}=43.574236 \% 2 \mathrm{C} 42.265672 \% 2 \mathrm{~F} 5.17$ (accessed on 6 July 2021).

Soil cover is a spatially differentiated Kastanozem complex [34] (complex of chestnut saline solonetzic soils [35]). The solonetzic morphological properties of soil are clearly noticeable in the Kastanozem complex. The salinization of the soil profile was inherited from the parent rock, an ancient seabed. The soil upper layer of the Kastanozem complex is saline and the non-toxic soluble salts content is about $0.2 \%$. The content of soluble salts sharply increases in deeper soil horizons up to $2.2 \%$. The soil complex components are the Haplic kastanozem and the Salic solonetz. These soil areas replace each other at short distances, up to several meters. In the pattern of the soil cover structure of the Kastanozem 
complex, the Salic solonetz is a less fertile soil negatively influencing the properties of the whole complex. Therefore, the Salic solonetz is a subject of land reclamation. At the same time, the chestnut soil itself bears stable signs of solonetz genesis.

The Haplic kastanozem is the main component of the Kastanozem complex (60-65\% of the complex area). The soil profile is $40-60 \mathrm{~cm}$ in depth and moderately solonized. The SOM content is $2.6 \%$, physical clay is $47.7 \%$, and clay is $29.5 \%$. The content of $\mathrm{CaCO}_{3}$ is $0.15 \%$ (up to $3-10 \%$ at a depth about $0.8-1.5 \mathrm{~m}$ ), and $\mathrm{pH}=7.6$. The exchangeable cation composition is: $\mathrm{Ca}^{2+} 182 \mathrm{mmol} \mathrm{kg}{ }^{-1}, \mathrm{Mg}^{2+} 65 \mathrm{mmol} \mathrm{kg}{ }^{-1}, \mathrm{Na}^{+} 34 \mathrm{mmol} \mathrm{kg}^{-1}$.

The Salic solonetz (35-40\% of the complex area) profile is about $40 \mathrm{~cm}$ in depth. The upper eluvial horizon of soil is about $10-20 \mathrm{~cm}$. The depth of the soil illuvial horizon is about $15-40 \mathrm{~cm}$. The transition soil horizon located beneath the illuvial soil horizon has a light brown coloration, inherited from the carbonate saline loess-like loam parent rock. The soil is saline and solonized. The solid residual is up to $2.0 \%$ in the soil transitional horizon and vadose zone. The SOM content is about $2.2 \%$, physical clay is $52.4 \%$, and clay is $34.2 \%$. The content of $\mathrm{CaCO}_{3}$ is $0.45 \%$ (up to $16 \%$ at a depth about $0.6 \mathrm{~m}$ ), and $\mathrm{pH}=7.9$. The $\mathrm{Na}^{+}$ion content is noticeable in the soil adsorption complex (SAC). The exchangeable $\mathrm{Na}^{+}$ content in SAC is up to $20 \%$ of cation exchange capacity (CEC) in the illuvial horizon of Salic solonetz. This content is by 1.5-2.0 times higher than that of Haplic kastanozem [33].

\subsection{Intra-Soil Milling Methodology}

Based on a heuristic approach to mechanical system synthesis, a device was developed for the processing of the illuvial soil horizon by the intra-soil milling method [36,37]. An objective of heuristic synthesis was to create a dispersed, fine, multilevel aggregated soil system for the priority biological process in the illuvial horizon. The tasks were to improve the conditions of organic matter synthesis; eliminate the soil surface erosion; higher soil productivity; and low energy consumption. The preset technical parameters for the device were as follows:

The total soil treatment layer was $45 \mathrm{~cm}$.

The upper $0-20 \mathrm{~cm}$ soil layer was processed by moldboard plowing.

The soil layer of $20-45 \mathrm{~cm}$ processing was performed by the milling ripper installed on the horizontal shaft.

The drive of the milling ripper by the closed drive gearing was mounted into the vertical passive ripper of two functions.

The first function was a passive loosening of the soil along the passage. The second function was that gearing transmits torque from the drive shaft to the horizontal milling shaft.

The width grip of the device was about $65 \mathrm{~cm}$.

\subsection{Sampling Strategy, Sampling Sights, and Soil Sampling,}

The soils were sampled from the wall of the soil profile section down to a $1.0 \mathrm{~m}$ depth $[38,39]$.

We chose a sampling strategy as a set forth plan to assure that the sample we use represents the variable Kastanozem complex terrain [38,40]. The sampling strategy of this study was based on the data and approach of the long-term research [41]. A singularity of the Kastanozem soil zone is the spatial variability at a distance about 10 to $100 \mathrm{~m}$. Individual solonetz areas differ from the surrounding soil at a distance of $10 \mathrm{~m}$. The solonetz area at the given location can be similar to the solonetz area several kilometers away. This feature of the spatial soil cover structure of Kastanozem is important for the soil sampling strategy reliability. The soil sampling strategy we used can be characterized as a combination of the model-based, zone, expert, and database approach [42,43].

The stages of the soil sampling strategy are as follows.

The soil samples were taken from every soil horizon from the cross-sections of the soil profile. The soil sample from the individual cross-section was a composite of the three samples taken from the different places of corresponding soil horizon in the profile cross- 
sections wall. A composite soil sample from every soil profile cross-section was accepted as an individual sample. There were three individual samples from the cross-section in the corresponding soil area of the Kastanozem complex to carry out a statistical procedure.

Soil geophysical properties were investigated according to Klute, 1986 [39]. Soil bulk density was determined into the soil profile by a metal ring pressed to the wall of cross-section at a given depth (intact core).

Soil aggregate analysis was fulfilled by the dry sieving method according to Nichols [44].

The soil aggregate composition before machining and the influence of the cutter type on the soil crumbling were studied in the field experiment. The size of the field site for each repetition for the cutter type studying was $5.0 \mathrm{~m}$ in length and $0.8 \mathrm{~m}$ in width. The size was chosen accounting for the width grip of PMS-70 of $0.65 \mathrm{~m}$. The registration area of every repetition of the experiment was located in the middle of the repetition site. The width and length of the registration area were $0.4 \mathrm{~m}$ and $0.5 \mathrm{~m}$, respectively. This choice of position of registration area eliminated the edge effect of the milling device penetration into the soil and its extraction from soil.

The study of the soil aggregate distribution after intra-soil milling was made by the Roentgen method [45]. Barium sulfate was a contrast agent for roentgenogram visualizing. This agent was placed into the soil profile before intra-soil milling. For that, the soil trench was prepared to be $2 \mathrm{~m}$ in length, $50 \mathrm{~cm}$ in width, to a depth of $35 \mathrm{~cm}$. On the trench bottom, a 1-2 mm barium sulfate layer was scattered. Then, the soil layers, removed before, returned to the initial position in the soil profile. While returning, the soil was sealed layer-by-layer to restore the natural bulk density. The $20-45 \mathrm{~cm}$ soil layer was milled by the PMS-70 alongside the strip. This provided elimination of the edge effects of the soil strip processing. After the strip intra-soil milling processing, the trench of $80 \mathrm{~cm}$ long and $20 \mathrm{~cm}$ wide was made in the middle of the strip perpendicular to the direction of the PMS-70 movement. The X-ray soil profile survey was performed using the trench.

The soil water regime was characterized by the thermodynamic potential of soil water (matric potential). The matric potential was calculated using the VG-equation for $\theta(h)$ Equation (1) [46]:

$$
\left(\theta-\theta_{r}\right) /\left(\theta_{s}-\theta_{r}\right)=1 /\left(1+\alpha h^{n}\right)^{m},
$$

where $\theta$ is the volumetric soil water content $\left(\mathrm{m}^{3} \mathrm{~m}^{-3}\right)$; $s$ and $r$ indicate saturated and residual values of soil water content, respectively; $h$ is the soil matric potential, $\mathrm{m}(1 \mathrm{MPa}=10 \mathrm{~m})$; $\alpha, n$, and $m$ are the empirical parameters affecting the shape of the retention curve [46]. For the $\alpha, n$, and $m$ calculations, the soil moisture was determined by oven drying at $105^{\circ} \mathrm{C}$ [39]. The soil water field capacity $(h=3.3 \mathrm{~m})$ was determined by oven drying at $105^{\circ} \mathrm{C}$. Soil water maximal hydroscopic capacity $\theta_{m h}(h=1500 \mathrm{~m})$ was determined by oven drying at $105^{\circ} \mathrm{C}$ followed by cooling to a temperature of $25^{\circ} \mathrm{C}$ at $98 \%$ air humidity. The soil water content at the wilting point (residual value of soil water $\theta_{r}$ ) was calculated via Equation (2):

$$
\theta_{r}=\theta_{w p}=1.3 \theta_{m h}
$$

The relative number of plant roots with diameters greater than $1 \mathrm{~mm}$ in the soil profile cross-section was determined as a quotient of dividing the number of roots across the area of determination $\left(20 \mathrm{~cm}^{2}\right)$ to $20 \mathrm{~cm}^{2}$.

An important element of the sampling strategy was a long-term field experiment in the rain-fed condition. The scheme of the experiment was as follows:

1. Moldboard plowing to a depth of $22 \mathrm{~cm}$ (standard farming technique).

2. Chiseling to a depth of $35 \mathrm{~cm}$.

3. Three-tier tillage to a depth of $45 \mathrm{~cm}$ by PTN-40 plow (standard soil amelioration technique).

4. Intra-soil milling of the $20-45 \mathrm{~cm}$ layer by PMC-70 device.

The randomized scheme of the experiment was in three replicates.

Ameliorative soil processing was carried out once in options 2-4 in 1972. After that, standard agriculture was applied in every experiment option. In the field experiment, the 
soil and plant samples were collected on the fixed plots in the area of every experiment repetition. The yield was accounted according to Janvry et al., 2017 [47].

\subsection{Soil Analyses}

The soil chemical properties were studied by water extraction of soluble salts, with the water to soil ratio (5:1). The procedure included forced shaking for $5 \mathrm{~min}$ and placing the mixture on a paper filter. The composition of the filtrate was studied by standard analytical methods. The soil dry residue (soluble salt content) was determined by oven drying at $105^{\circ} \mathrm{C}$ [40]. The $\mathrm{pH}$ was determined at $20^{\circ} \mathrm{C}$ by a pH-meter using an ion meter with a glass electrode (TITAN, Tom Analit Ltd., St. Petersburg, Russia).

The soil physicochemical properties (an absorbed cation-anion composition) were determined using the standard method for the soils of high carbonate content (SW-846) [48].

The SOM content was determined by a wet oxidation procedure, i.e., the WalkleyBlack (WB) method [49,50].

The parameters were studied in triplicate. Calculations of the associated errors and statistical significance of the data were performed with Statistica v.10.0.1011, developed by StatSoft (Tulsa, USA, www.statsoft.com, accessed on 6 July 2021). All data presented in the tables (mean \pm standard deviation) and in the text were statistically significant at $p<0.05$.

\section{Results}

\subsection{Soil Milling Cutters and Device}

The soil milling cutters (Figure 2) and the intra-soil milling device (Figure 3) were developed [37].
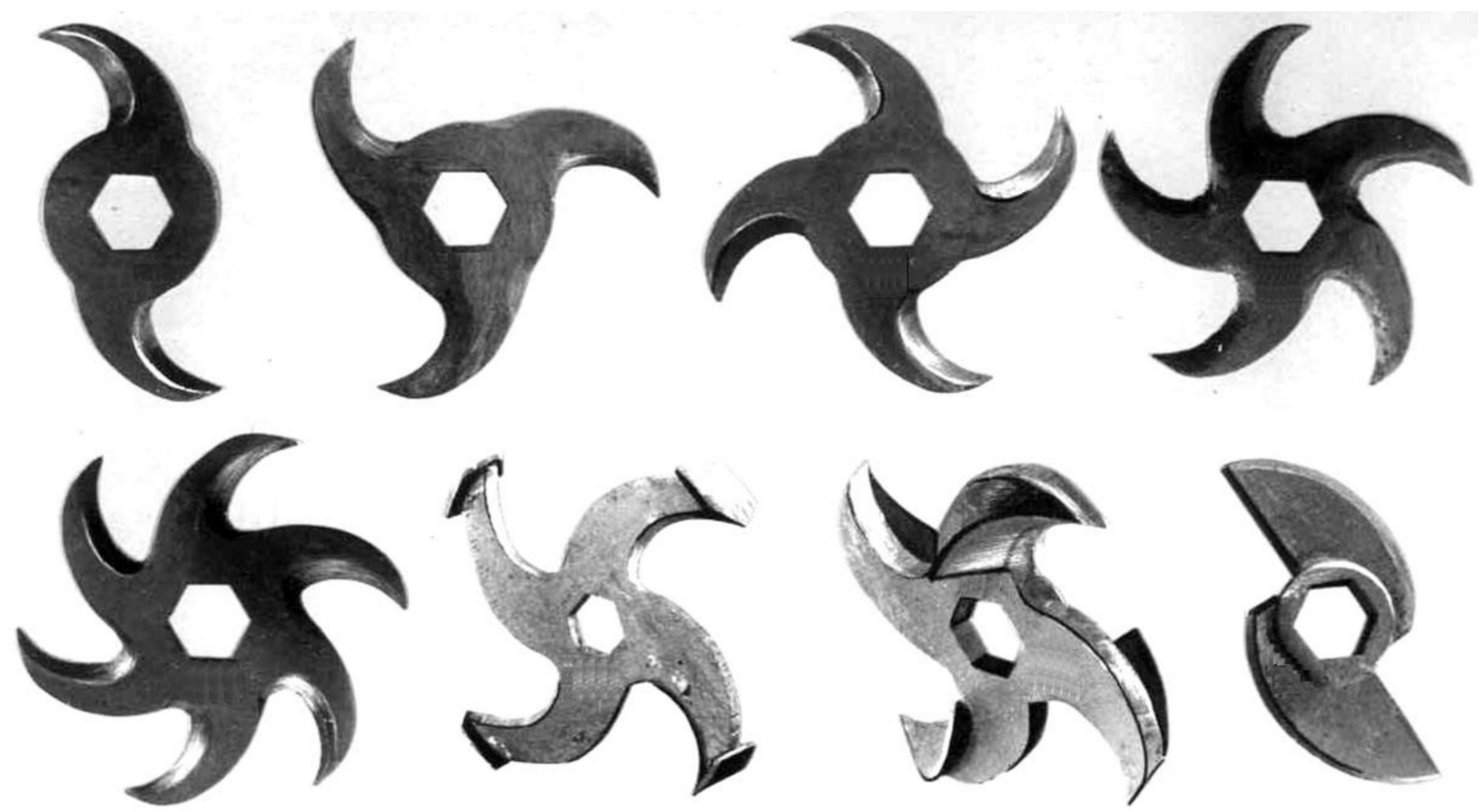

Figure 2. Disk cutters for intra-soil milling processing. From left to right, above: Two-teeth milling cutter; three-teeth milling cutter; four-teeth milling cutter; five-teeth milling cutter; below: Six-teeth milling cutter; four-teeth milling cutter with an expanded working body; four-teeth combined milling cutter with dumps; two-teeth screw milling cutter. 


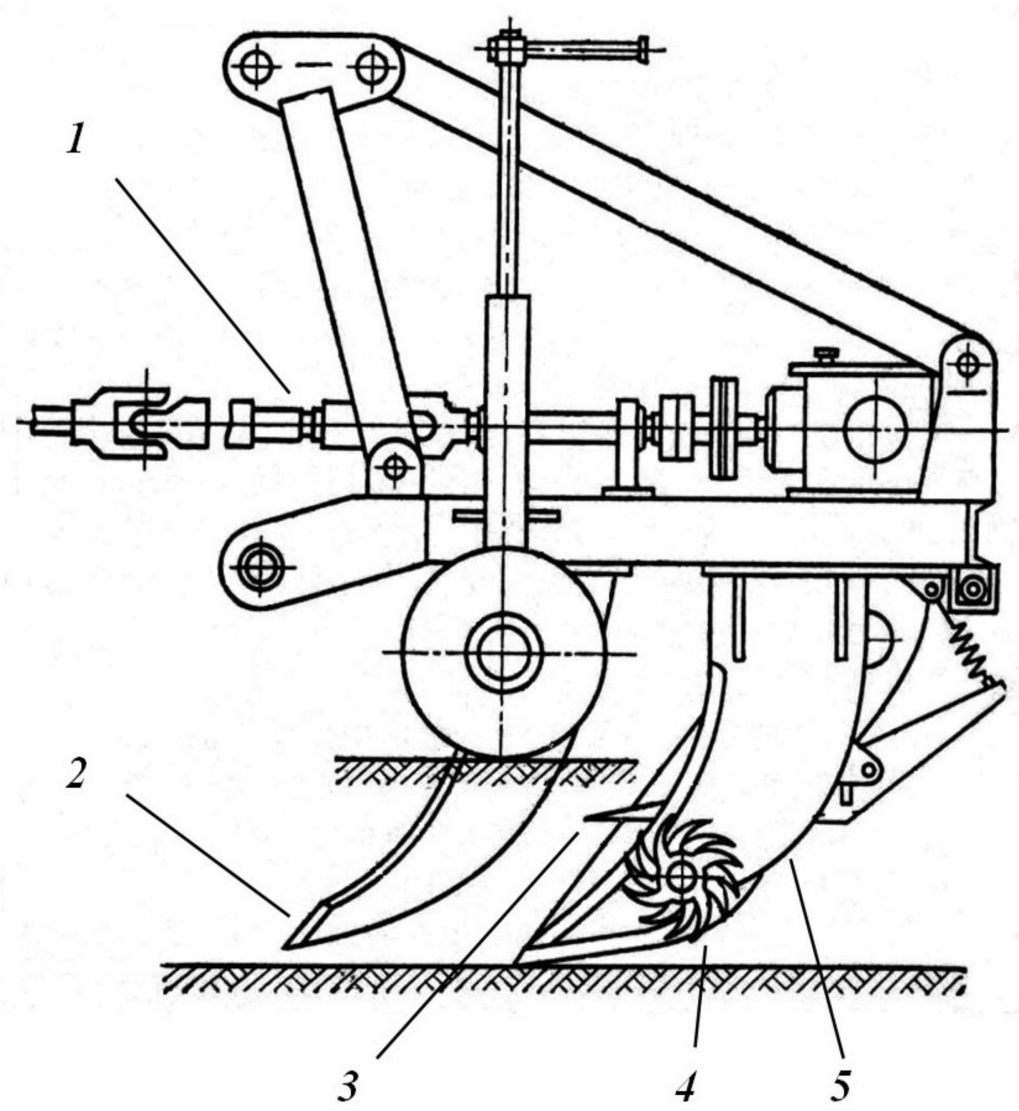

Figure 3. Mechanical scheme of intra-soil milling device. Mechanical drive 1, chisel for preliminary soil loosening 2, moldboard plow section 3, soil illuvial and transitional horizons milling ripper 4, passive ripper with closed gearing housing 5 .

The device (Figure 3) was equipped with a moldboard section 3. This passive working body provided plowing of the soil upper layer of $0-20 \mathrm{~cm}$. The device had a mechanical drive 1 connected to the power take-off shaft. The chisel for preliminary soil loosening 2 formed a slit in front of the passive ripper 5 . The passive ripper 5 loosened the soil along its passage. Simultaneously, the passive ripper 5 was closed housing for the transmission drive gearing. The drive gearing transmitted the torque to the milling ripper 4 . The milling cutters of $250 \mathrm{~mm}$ diameter were installed vertically with a spacing of $80 \mathrm{~mm}$ along the horizontal shaft of milling ripper 4 . The milling ripper 4 processed the illuvial and transitional horizons of soil in layers $20-45 \mathrm{~cm}$. The rotation speed was about $500 \mathrm{rpm}$.

\subsection{Soil Geophysical Properties Depending on the Mill Type}

The aggregates composition data in the control option of the experiment (not milled soil) are given in Table 1. The layers for studying the soil geophysical properties were selected according to the standard of agrochemical studies. The data showed a low percentage of the soil fine aggregates preferable for the SOM formation, soil amelioration, and better plant growth.

Table 1. Soil aggregate composition of the solonetz before processing (dry sieving), \%.

\begin{tabular}{ccccccc}
\hline \multirow{2}{*}{ Depth, cm } & \multicolumn{7}{c}{ Fraction, $\mathbf{m m}$} \\
& $>\mathbf{1 0}$ & $\mathbf{3 - 1 0}$ & $\mathbf{1 - 3}$ & $\mathbf{0 . 2 5 - 1}$ & $<\mathbf{0 . 2 5}$ & $\mathbf{\Sigma}(\mathbf{1 - 1 0} \mathbf{m m})$ \\
\hline $0-20$ & $72.5 \pm 7.1$ & $10.2 \pm 2.7$ & $4.3 \pm 1.5$ & $1.8 \pm 0.8$ & $11.2 \pm 3.0$ & 14.5 \\
\hline $20-40$ & $58.2 \pm 6.0$ & $13.2 \pm 2.6$ & $11.1 \pm 2.8$ & $11.3 \pm 2.5$ & $6.2 \pm 2.7$ & 24.3 \\
\hline
\end{tabular}


A soil aggregate composition after intra-soil milling is presented in Table 2. The soil layers for sampling were selected accounting for the PMS-70 device design [51,52]. The layer of sampling of $0-15 \mathrm{~cm}$ was less than the depth of the intact soil layer $0-20 \mathrm{~cm}$ to exclude the marginal transition effect of soil milling in the $20-45 \mathrm{~cm}$ layer. As layer $0-15$ was not processed, the data for this layer were borrowed from Table 1 . The content of the $>10$ fraction in transition layer 15-30 cm was less than in the intact layer 0-15 cm. At the same time, this content was higher compared to the mill processed $30-45 \mathrm{~cm}$ layer. All types of the studied milling cutters provided a statistically significant change in the soil aggregate composition (Table 2). The six-teeth milling cutter provided the best soil crushing in the layer $30-45 \mathrm{~cm}$, and the content of preferable for plant growth soil aggregate fraction 1-3 mm was maximal. In other options of milling cutter type, this content was a little bit less. However, in every option of the milling cutter type, the soil aggregate fraction 1-3 mm content was many times higher than that in the initial soil (Table 1). According to the Table 2 data, every milling cutter type provided the soil aggregate composition preferable for the plant root growth.

Table 2. Soil crumbling depending on the milling cutter type, \% (dry sieving).

\begin{tabular}{|c|c|c|c|c|c|c|c|}
\hline \multirow{2}{*}{ Mill Cutter Type } & \multirow{2}{*}{ Depth, $\mathrm{cm}$} & \multicolumn{6}{|c|}{ Fraction, $\mathrm{mm}$} \\
\hline & & $>10$ & $3-10$ & $1-3$ & $0.25-1$ & $<0.25$ & $\Sigma(1-10 \mathrm{~mm})$ \\
\hline \multirow{3}{*}{ Four-teeth milling cutter } & $0-15$ & $72.5 \pm 7.1$ & $10.2 \pm 2.7$ & $4.3 \pm 1.5$ & $1.8 \pm 0.8$ & $11.2 \pm 3.0$ & 14.5 \\
\hline & $15-30$ & $42.2 \pm 6.9$ & $23.4 \pm 3.2$ & $18.3 \pm 4.6$ & $9.8 \pm 2.3$ & $6.30 \pm 2.5$ & 41.7 \\
\hline & $30-45$ & $18.9 \pm 3.0$ & $32.9 \pm 4.6$ & $27.1 \pm 5.2$ & $10.9 \pm 2.2$ & $10.2 \pm 2.2$ & 60.0 \\
\hline \multirow{3}{*}{ Five-teeth milling cutter } & $0-15$ & $72.5 \pm 7.1$ & $10.2 \pm 2.7$ & $4.3 \pm 1.5$ & $1.8 \pm 0.8$ & $11.2 \pm 3.0$ & 14.5 \\
\hline & $15-30$ & $34.1 \pm 6.8$ & $27.4 \pm 5.1$ & $23.9 \pm 3.2$ & $8.6 \pm 2.0$ & $6.0 \pm 2.6$ & 51.3 \\
\hline & $30-45$ & $12.2 \pm 2.7$ & $27.1 \pm 5.5$ & $33.2 \pm 3.6$ & $13.9 \pm 2.1$ & $13.6 \pm 3.2$ & 60.3 \\
\hline \multirow{3}{*}{ Six-teeth milling cutter } & $0-15$ & $72.5 \pm 7.1$ & $10.2 \pm 2.7$ & $4.3 \pm 1.5$ & $1.8 \pm 0.8$ & $11.2 \pm 3.0$ & 14.5 \\
\hline & $15-30$ & $13.1 \pm 3.0$ & $23.3 \pm 4.5$ & $33.7 \pm 4.0$ & $13.30 \pm 3.1$ & $16.7 \pm 3.5$ & 57.0 \\
\hline & $30-45$ & $4.7 \pm 1.2$ & $26.0 \pm 3.0$ & $37.3 \pm 6.8$ & $16.7 \pm 3.2$ & $15.3 \pm 2.5$ & 63.3 \\
\hline \multirow{3}{*}{$\begin{array}{l}\text { Four-teeth cutter with } \\
\text { expanded working body }\end{array}$} & $0-15$ & $72.5 \pm 7.1$ & $10.2 \pm 2.7$ & $4.3 \pm 1.5$ & $1.8 \pm 0.8$ & $11.2 \pm 3.0$ & 14.5 \\
\hline & $15-30$ & $24.7 \pm 3.5$ & $25.0 \pm 3.0$ & $27.0 \pm 5.0$ & $13.0 \pm 3.6$ & $10.3 \pm 2.5$ & 52.0 \\
\hline & $30-45$ & $8.8 \pm 2.3$ & $25.3 \pm 3.5$ & $34.0 \pm 4.0$ & $16.8 \pm 2.9$ & $15.1 \pm 2.5$ & 59.3 \\
\hline \multirow{3}{*}{$\begin{array}{l}\text { Four-teeth combined } \\
\text { cutter with dumps }\end{array}$} & $0-15$ & $72.5 \pm 7.1$ & $10.2 \pm 2.7$ & $4.3 \pm 1.5$ & $1.8 \pm 0.8$ & $11.2 \pm 3.0$ & 14.5 \\
\hline & $15-30$ & $29.5 \pm 3.7$ & $27.0 \pm 2.0$ & $24.7 \pm 3.1$ & $11.3 \pm 3.1$ & $7.5 \pm 2.2$ & 51.7 \\
\hline & $30-45$ & $18.0 \pm 3.6$ & $30.3 \pm 4.9$ & $28.0 \pm 3.6$ & $12.0 \pm 2.0$ & $11.7 \pm 2.1$ & 58.3 \\
\hline
\end{tabular}

The result of intra-soil crumbling and mixing is visible on the X-ray photos of the barium sulfate scattering field (Figure 4) [53]. 


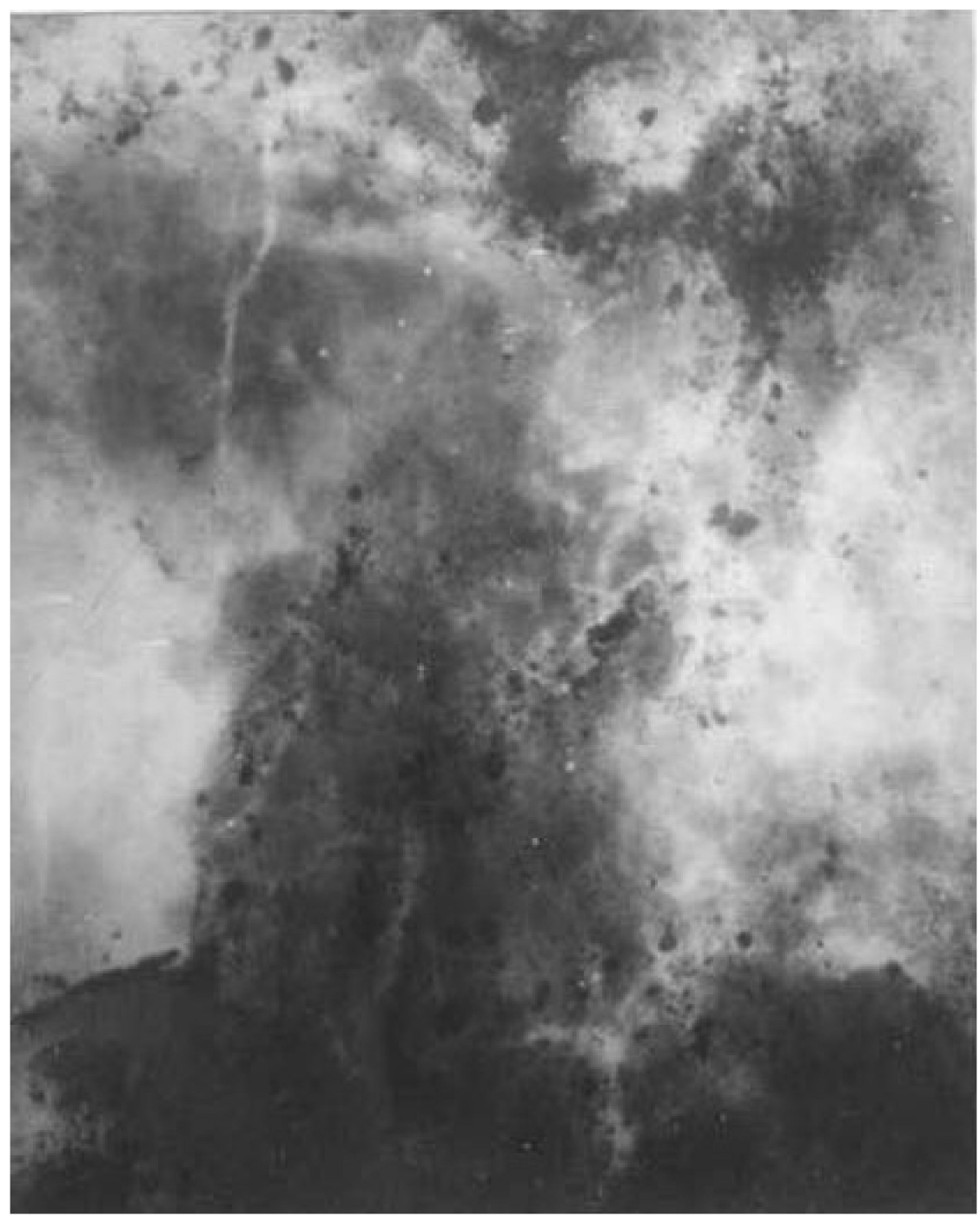

Figure 4. X-ray diffraction in soil on barium sulfate particles after PMS-70 intra-soil processing.

\subsection{Long-Term Change of the Soil Geophysical Properties}

The crushing and mixing of the aggregates in the treated soil layer have been characterized quantitatively (Table 3). The soil aggregate composition indicates the soil geophysical structure as unsatisfactory for the plat growth after moldboard. The loosening effect of soil chiseling was low. While three-tier plowing, up to $25 \%$ of the material of the illuvial horizon entered the $0-20 \mathrm{~cm}$ soil layer. Conversely, $35 \%$ of the amount of the upper soil humus horizon strewed down the soil profile between large structural blocks of illuvial and transitional horizons. The content of the artificial aggregate particle fraction of 1-3 mm size was high in the illuvial soil horizon after PMS-70.

According to the data of Table 3, the initial aggregates became larger in a course of the soil evolution after milling processing of the $20-45 \mathrm{~cm}$ layer. The aggregates of the $>10 \mathrm{~mm}$ size acquires the mechanical shear stress zones after milling cutter impact. Thus, the artificial aggregates become more accessible for the active soil amelioration process. All soil aggregates remain easily permeable for the root system until now.

The dynamics of the soil aggregate composition after different options of soil mechanical treatment influence the corresponding dynamics of other soil properties. In order to not overload the paper with data, below we presented only the resulting figures on the bulk density of soil (Section 3.3.1), soil morphological properties and root development (Section 3.4), soil moisture content (Section 3.5), soil chemical properties (Section 3.6), soil physicochemical properties (Section 3.7), soil organic matter (Section 3.8), biometric pa- 
rameters of agrophytocenosis (Section 3.9), and economical efficacy of the soil mechanical processing (Section 3.9.1).

Table 3. Solonetz soil profile aggregate composition after soil mechanical treatment. Dry sieving fractions, \%. Experimental site "Kolkhoz Leninsky Put'".

\begin{tabular}{|c|c|c|c|c|c|c|c|}
\hline Soil Processing & Depth, cm & $>10 \mathrm{~mm}$ & 5-10 mm & $3-5 \mathrm{~mm}$ & $1-3 \mathrm{~mm}$ & $1-0.25 \mathrm{~mm}$ & $<0.25 \mathrm{~mm}$ \\
\hline \multirow{3}{*}{$\begin{array}{c}1972 \\
\text { Before soil processing }\end{array}$} & & & & & & & \\
\hline & $0-20$ & $68.7 \pm 5.0$ & $9.6 \pm 2.1$ & $5.0 \pm 1.7$ & $8.2 \pm 1.6$ & $5.2 \pm 1.6$ & $3.3 \pm 1.3$ \\
\hline & $20-40$ & $39.0 \pm 5.6$ & $15.3 \pm 2.6$ & $12.6 \pm 2.8$ & $21.3 \pm 4.5$ & $7.0 \pm 1.0$ & $4.8 \pm 1.1$ \\
\hline \multirow[t]{2}{*}{ Moldboard plowing, depth $22 \mathrm{~cm}$ (control) } & $0-20$ & $58.8 \pm 5.7$ & $10.2 \pm 1.6$ & $7.2 \pm 2.3$ & $14.4 \pm 2.4$ & $5.8 \pm 1.8$ & $3.6 \pm 1.0$ \\
\hline & $20-40$ & $46.1 \pm 5.5$ & $18.1 \pm 3.2$ & $11.8 \pm 2.7$ & $17.1 \pm 2.8$ & $4.5 \pm 1.9$ & $2.4 \pm 0.8$ \\
\hline \multirow[t]{2}{*}{ Chiseling, depth $35 \mathrm{~cm}$} & $0-20$ & $58.8 \pm 5.7$ & $10.2 \pm 1.6$ & $7.2 \pm 2.3$ & $14.4 \pm 2.4$ & $5.8 \pm 1.8$ & $3.6 \pm 1.0$ \\
\hline & $20-40$ & $46.1 \pm 5.5$ & $18.1 \pm 3.2$ & $11.8 \pm 2.7$ & $17.1 \pm 2.8$ & $4.5 \pm 1.9$ & $2.4 \pm 0.8$ \\
\hline \multirow[t]{2}{*}{ Three tier soil tillage PTN-40, depth $45 \mathrm{~cm}$} & $0-20$ & $48.3 \pm 6.0$ & $14.1 \pm 3.0$ & $11.3 \pm 2.5$ & $15.9 \pm 3.6$ & $4.7 \pm 2.1$ & $5.7 \pm 1.5$ \\
\hline & $20-40$ & $39.8 \pm 4.8$ & $13.0 \pm 3.6$ & $10.9 \pm 3.0$ & $20.8 \pm 4.5$ & $7.3 \pm 2.5$ & $8.2 \pm 1.7$ \\
\hline \multirow[t]{2}{*}{ Soil milling PMS-70, layer $20-45 \mathrm{~cm}$} & $0-20$ & $44.4 \pm 5.8$ & $13.9 \pm 1.9$ & $12.5 \pm 2.7$ & $18.2 \pm 3.4$ & $8.5 \pm 2.5$ & $2.5 \pm 0.8$ \\
\hline & $20-40$ & $11.0 \pm 4$ & $10.4 \pm 3.1$ & $9.9 \pm 3.0$ & $39.6 \pm 4.6$ & $16.7 \pm 3.2$ & $12.4 \pm 1.6$ \\
\hline \multicolumn{8}{|l|}{2008} \\
\hline \multirow[t]{2}{*}{ Moldboard plowing, depth $22 \mathrm{~cm}$ (control) } & $0-20$ & $47.4 \pm 6.5$ & $11.0 \pm 3.6$ & $8.2 \pm 1.4$ & $18.4 \pm 2.9$ & $7.8 \pm 1.6$ & $7.2 \pm 2.0$ \\
\hline & $20-40$ & $49.9 \pm 4.0$ & $13.1 \pm 3.2$ & $12.9 \pm 2.8$ & $14.0 \pm 2.0$ & $7.2 \pm 1.7$ & $2.9 \pm 1.0$ \\
\hline \multirow[t]{2}{*}{ Chiseling, depth $35 \mathrm{~cm}$} & $0-20$ & $57.2 \pm 6.2$ & $11.1 \pm 2.6$ & $9.0 \pm 2.6$ & $12.9 \pm 3.4$ & $4.9 \pm 1.9$ & $4.9 \pm 1.5$ \\
\hline & $20-40$ & $47.1 \pm 5.9$ & $18.9 \pm 3.9$ & $12.8 \pm 2.4$ & $14.8 \pm 2.4$ & $4.3 \pm 1.5$ & $2.1 \pm 0.8$ \\
\hline \multirow[t]{2}{*}{ Three tier soil tillage PTN-40, depth $45 \mathrm{~cm}$} & $0-20$ & $39.8 \pm 5.8$ & $11.6 \pm 3.5$ & $13.8 \pm 3.0$ & $18.1 \pm 3.9$ & $10.5 \pm 2.7$ & $6.2 \pm 1.7$ \\
\hline & $20-40$ & $43.4 \pm 7.4$ & $14.1 \pm 2.5$ & $15.5 \pm 2.8$ & $15.8 \pm 3.3$ & $6.1 \pm 1.8$ & $5.1 \pm 1.2$ \\
\hline \multirow[t]{2}{*}{ Soil milling PMS-70, layer $20-45 \mathrm{~cm}$} & $0-20$ & $24.1 \pm 7.4$ & $16.7 \pm 3.2$ & $17.5 \pm 5.4$ & $22.3 \pm 5.7$ & $12.5 \pm 2.3$ & $6.9 \pm 2.0$ \\
\hline & $20-40$ & $14.0 \pm 4.6$ & $13.4 \pm 3.5$ & $19.2 \pm 3.4$ & $31.8 \pm 4.0$ & $15.2 \pm 3.3$ & $6.4 \pm 2.3$ \\
\hline \multicolumn{8}{|l|}{2019} \\
\hline \multirow[t]{2}{*}{ Moldboard plowing, depth $22 \mathrm{~cm}$ (control) } & $0-20$ & $63.0 \pm 8.2$ & $10.3 \pm 3.2$ & $6.1 \pm 1.7$ & $10.2 \pm 3.4$ & $4.9 \pm 1.1$ & $5.5 \pm 1.5$ \\
\hline & $20-40$ & $45.2 \pm 6.0$ & $16.3 \pm 2.5$ & $13.6 \pm 3.9$ & $16.2 \pm 2.3$ & $5.4 \pm 1.5$ & $3.3 \pm 1.5$ \\
\hline \multirow[t]{2}{*}{ Chiseling, depth $35 \mathrm{~cm}$} & $0-20$ & $45.3 \pm 6.1$ & $12.3 \pm 2.5$ & $11.8 \pm 2.4$ & $17.0 \pm 4.6$ & $8.2 \pm 1.7$ & $5.4 \pm 1.4$ \\
\hline & $20-40$ & $45.1 \pm 7.1$ & $13.3 \pm 3.5$ & $11.8 \pm 2.7$ & $15.6 \pm 2.5$ & $7.9 \pm 1.2$ & $6.3 \pm 1.5$ \\
\hline \multirow[t]{2}{*}{ Three tier soil tillage PTN-40, depth $45 \mathrm{~cm}$} & $0-20$ & $43.9 \pm 6.1$ & $12.0 \pm 2.0$ & $11.4 \pm 2.4$ & $17.2 \pm 2.7$ & $9.5 \pm 1.9$ & $6.0 \pm 1.0$ \\
\hline & $20-40$ & $43.4 \pm 7.4$ & $14.1 \pm 2.5$ & $15.5 \pm 2.8$ & $15.8 \pm 3.3$ & $6.1 \pm 1.8$ & $5.1 \pm 1.2$ \\
\hline \multirow[t]{2}{*}{ Soil milling PMS-70, layer $20-45 \mathrm{~cm}$} & $0-20$ & $29.4 \pm 4.4$ & $14.6 \pm 3.1$ & $15.1 \pm 3.8$ & $24.0 \pm 3.0$ & $10.9 \pm 2.7$ & $6.0 \pm 2.0$ \\
\hline & $20-40$ & $13.0 \pm 4.0$ & $12.2 \pm 2.7$ & $16.1 \pm 3.6$ & $33.3 \pm 5.5$ & $17.1 \pm 2.7$ & $8.3 \pm 2.5$ \\
\hline
\end{tabular}

Note: The 1972, 2008 data borrowed from Kalinichenko et al., 2011.

3.3.1. Bulk Density of Soil after Different Options of Mechanical Treatment

With respect to the Table 4 data, the soil bulk density after moldboard plowing was close to the $1.35 \mathrm{t} \mathrm{m}^{-3}$ value, which is critical for the plant growth on the Kastanozem [15].

Table 4. Soil bulk density after different options of soil mechanical treatment.

\begin{tabular}{ccc}
\hline Soil Processing & Depth, cm & Bulk Density, $\mathbf{t ~ m}^{-\mathbf{3}}$ \\
\hline 2019 & & \\
\hline \multirow{2}{*}{ Moldboard plowing, depth $22 \mathrm{~cm}$ (control) } & $0-20$ & $1.32 \pm 0.05$ \\
& $20-40$ & $1.51 \pm 0.06$ \\
\hline \multirow{2}{*}{ Chiseling, depth $35 \mathrm{~cm}$} & $0-20$ & $1.34 \pm 0.04$ \\
& $20-40$ & $1.49 \pm 0.06$ \\
\hline \multirow{2}{*}{ Three tier soil tillage PTN-40, depth 45 cm } & $0-20$ & $1.31 \pm 0.06$ \\
& $20-40$ & $1.43 \pm 0.08$ \\
\hline \multirow{2}{*}{ Soil milling PMS-70, layer 20-45 cm } & $0-20$ & $1.25 \pm 0.04$ \\
& $20-40$ & $1.35 \pm 0.05$ \\
\hline
\end{tabular}


Almost the same adverse data on the bulk density of soil were registered after chiseling. Compared with the moldboard plowing and chiseling, the soil bulk density was slightly less after PTN-40 plowing because of better soil loosening.

After PMS-70, the long-term soil bulk density figures (Table 4) were less compared to the moldboard plowing, chiseling, and PTN-40 plowing. In the PMS-70 option of the field experiment, the soil bulk density was optimal for the plant growth and sustainable soil evolution in the processed soil layer $20-45 \mathrm{~cm}$ and in the upper soil layer $0-20 \mathrm{~cm}$. The last effect is a consequence of the improved conditions for plant and soil biota development. Intra-soil processing positively influenced the 0-20 layer indirectly.

\subsection{Soil Morphological Properties and Root Development after Different Options of Mechanical Treatment}

The data on the root development are presented in Table 5.

Table 5. Root development after different options of soil mechanical treatment.

\begin{tabular}{ccc}
\hline Soil Processing & Depth, cm & $\begin{array}{c}\text { Number of Plant Roots D > 1 mm } \\
\text { in Soil Profile, pcs cm }\end{array}$ \\
\hline 2019 & & \\
\hline Moldboard plowing, depth $22 \mathrm{~cm}$ (control) & $0-20$ & $1.3 \pm 0.6$ \\
Chiseling, depth $35 \mathrm{~cm}$ & $20-40$ & $0.2 \pm 0.1$ \\
\hline \multirow{2}{*}{ Three tier soil tillage PTN-40, depth $45 \mathrm{~cm}$} & $0-20$ & $1.5 \pm 0.9$ \\
& $20-40$ & $0.3 \pm 0.2$ \\
\hline \multirow{2}{*}{ Soil milling PMS-70, layer 20-45 cm } & $0-20$ & $1.7 \pm 1.2$ \\
& $0-20$ & $0.7 \pm 0.3$ \\
\hline
\end{tabular}

The standard moldboard plowing of the $0-22 \mathrm{~cm}$ soil layer (control option) does not change the adverse consequences of the solonetz pedogenesis. The vertical morphological differentiation of the soil horizons remained visible. The eluvial horizon had a brown color. Its structure was coarse. The illuvial horizon had a darker color, grayish at the top. Its structure was dense. The rhizosphere developed only in the upper soil layer 0-20 cm in the control option of the experiment (Table 5). This feature of the standard moldboard plowing is obvious in Figure 5, where the plant roots are visible only in the eluvial horizon of the soil.

After chiseling, the morphological properties of the soil and the spread of rhizosphere were not noticeably different compared to the control option of experiment.

In the option of three-tier PTN-40 plowing, the large soil blocks of illuvial and transitional horizons partly moved to the upper soil horizon. Accordingly, the upper soil horizon blocks partly sank to the lower horizons of the soil. This ameliorative plowing option provided some possibility for the root system expansion down into the soil profile due to mechanical perturbation of the soil profile. The conditions for rhizosphere development were better in the 0-20 cm upper soil layer, as well as in the deeper soil layer of $20-40 \mathrm{~cm}$ in the option of three-tier PTN-40 plowing. The roots grew in the soil layer of $20-40 \mathrm{~cm}$ in the areas, where some part of the fine particles of the surface soil horizon got between the blocks of illuvial and transition soil horizons after three-tier PTN-40 plowing (Table 5). Figure 6 shows that the blocks of the illuvial and transition horizons remain unchanged long-term after three-tier PTN-40 plowing. This is an obstacle for the root development in this option of the field experiment. 


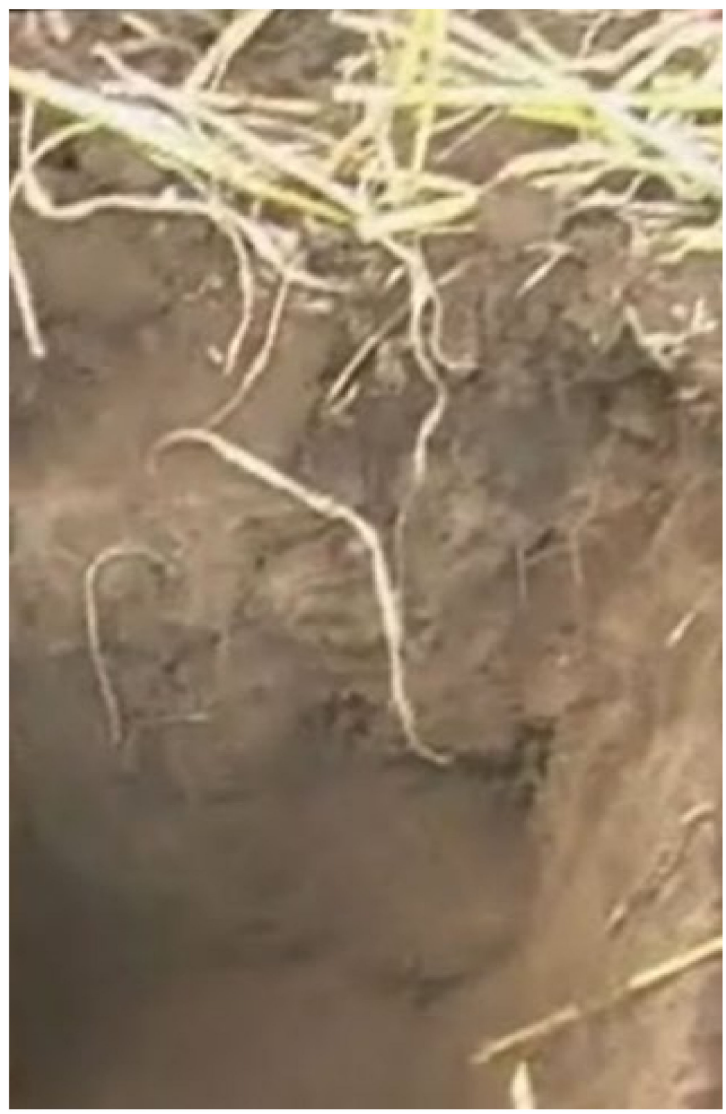

Figure 5. Solonetz soil profile wall in the layer $0-35 \mathrm{~cm}$ after moldboard plowing. Eluvial $(0-18 \mathrm{~cm})$ and illuvial $(18-35 \mathrm{~cm})$ soil horizons.

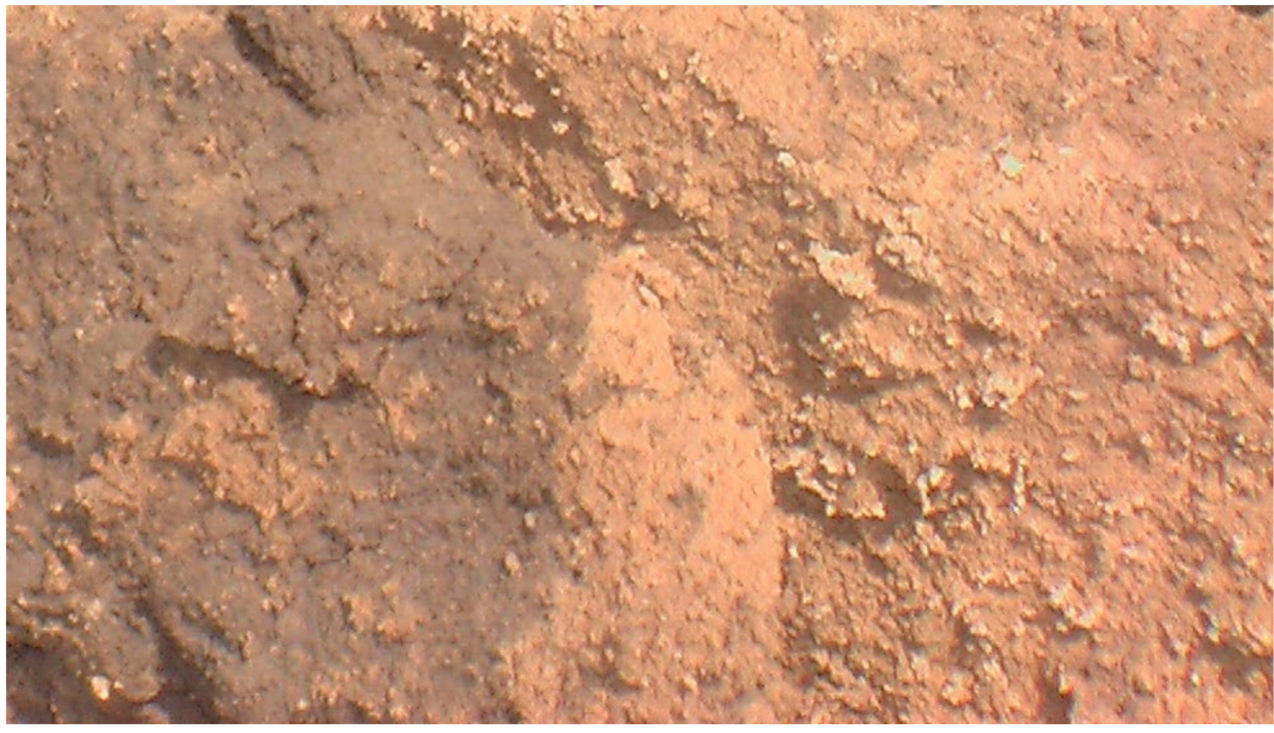

Figure 6. Solonetz profile wall at a depth about $20-35 \mathrm{~cm}$ (40 years after the PTN-40 plowing).

After PMS-70 intra-soil processing, the soil layer $20-45 \mathrm{~cm}$ acquired a uniform darkbrown color and become morphologically homogenous. In consequence, the soil geophysical and morphological properties become much more suitable for plant root development. The rhizosphere developed uniformly both in the upper $0-20 \mathrm{~cm}$ and in the milled $20-45 \mathrm{~cm}$ soil layer. The root system architecture became well developed and spread uniformly throughout the soil profile, and the thin roots predominated (Table 5). The homogenous 
soil layer 20-45 cm after PMS-70 intra-soil processing presented in Figure 7. This figure shows that the soil structure and architecture become favorable for the development of roots in the whole soil profile. The soil cross-section wall riddled with roots.

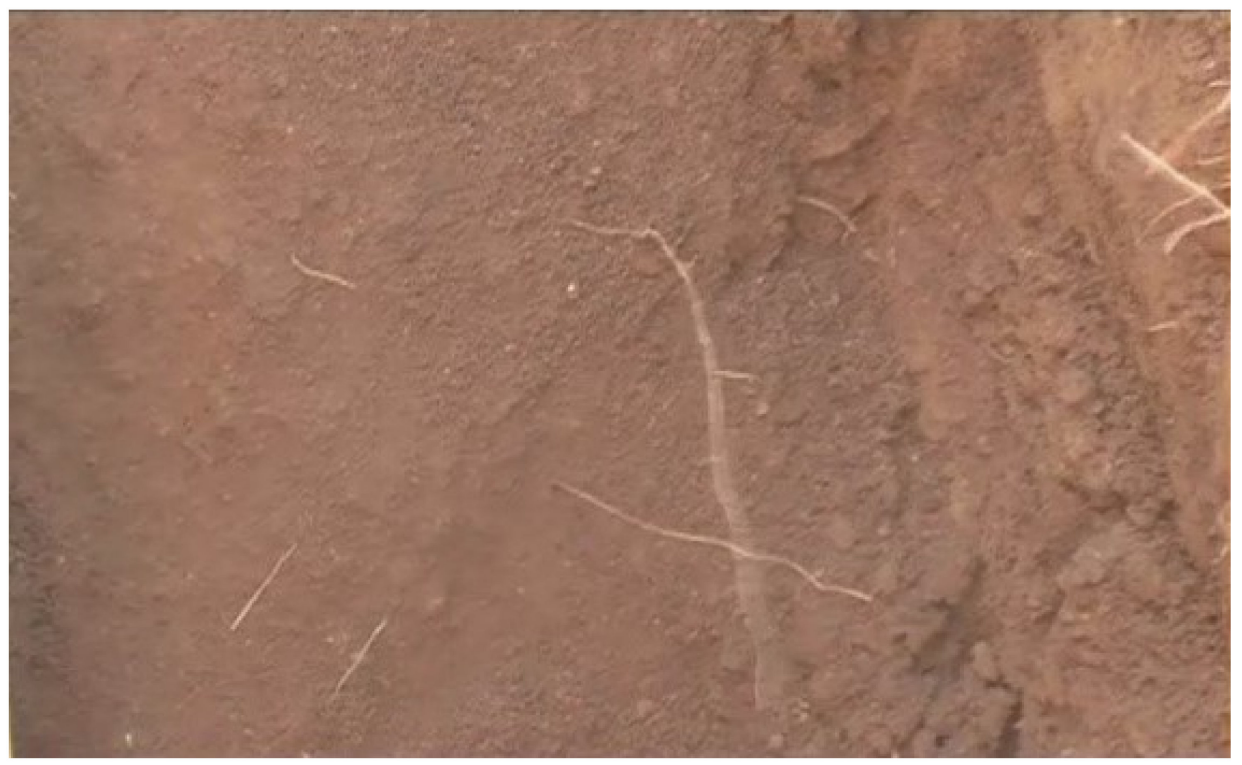

Figure 7. Solonetz soil profile wall at a depth of $25-40 \mathrm{~cm}$ (40 years after PMS-70 processing).

\subsection{Soil Moisture Content after Different Options of Mechanical Treatment}

The data on the soil water content are presented in the form of matric water potential (Table 6).

Table 6. Matric water potential after different options of soil mechanical treatment.

\begin{tabular}{cccc}
\hline Soil Processing & Depth, cm & $\begin{array}{c}\text { Matric Water } \\
\text { Potential, MPa, Earing } \\
\text { Stage }\end{array}$ & $\begin{array}{c}\text { Matric Water } \\
\text { Potential, MPa, Wax } \\
\text { Ripeness Stage }\end{array}$ \\
\hline 2019 & & & \\
\hline $\begin{array}{c}\text { Moldboard plowing, depth } \\
\text { 22 cm (control) }\end{array}$ & $0-20$ & $-0.07 \pm 0.01$ & $-0.57 \pm 0.15$ \\
\hline Chiseling, depth 35 cm & $0-20$ & $-0.04 \pm 0.02$ & $-0.47 \pm 0.12$ \\
\hline Three tier soil tillage PTN-40, & $0-20$ & $-0.08 \pm 0.02$ & $-0.60 \pm 0.10$ \\
depth 45 cm & $20-40$ & $-0.04 \pm 0.01$ & $-0.48 \pm 0.18$ \\
\hline Soil milling PMS-70, layer & $0-20$ & $-0.08 \pm 0.05$ & $-0.55 \pm 0.10$ \\
20-45 cm & $20-40$ & $-0.04 \pm 0.02$ & $-0.44 \pm 0.14$ \\
\hline
\end{tabular}

In the control option of the experiment, the mean soil moisture content was low in the Kastanozem complex during the vegetation season. The low matric water potential limited rain-fed plant growth. The slightly improved soil moisture regime was revealed only in the first 3-4 years after chiseling [45]. In 2019, the matric water potential in this option of field experiment was the same to the control option. After the PTN-40 processing, the precipitations entered the soil deeper horizons better than after moldboard plowing or chiseling, but to a limited extent. In general, the soil moisture regime after moldboard plowing, chiseling, and three-tier plowing followed a regional pattern. The matric water potential was low for plant comfort growth.

The soil profile was loose and homogeneous after PMS-70 processing. The soil moves to the root system from both: the fine soil macro-aggregates (initial soil aggregates) and 
the freshly formed micro-aggregates (PMS-70 result). This provided an improved soil water regime compared other options of the field experiment (Table 6). Plants consumed water freely. The rate of consumption of water, nutrients, and energy for the production of biomass was less after PMS-70 processing. The data on the matrix potential show that PMS-70 processing ensures soil water saving. At the same natural humidification rate, the intra-soil processing provided better conditions for the plants organogenesis and a higher yield compared to other options in the experiment.

3.6. Soil Chemical Properties after Different Options of Mechanical Treatment

Soil chemical properties differ in the options of the experiment (Table 7).

Table 7. Soil chemical properties after different options of mechanical treatment.

\begin{tabular}{cccc}
\hline Soil Processing & Depth, cm & Soil Salinization, \% & pH \\
\hline 2019 & & & \\
\hline \multirow{2}{*}{ Moldboard plowing, depth 22 cm (control) } & $0-40$ & $0.078 \pm 0.016$ & $7.4 \pm 0.3$ \\
& $40-60$ & $0.61 \pm 0.11$ & $7.9 \pm 0.2$ \\
\hline Chiseling, depth 35 cm & $0-40$ & $0.089 \pm 0.018$ & $7.4 \pm 0.2$ \\
& $40-60$ & $0.52 \pm 0.08$ & $7.9 \pm 0.2$ \\
\hline \multirow{2}{*}{ Three tier soil tillage PTN-40, depth 45 cm } & $0-40$ & $0.066 \pm 0.005$ & $7.3 \pm 0.2$ \\
& $40-60$ & $0.46 \pm 0.08$ & $7.5 \pm 0.2$ \\
\hline \multirow{2}{*}{ Soil milling PMS-70, layer 20-45 cm } & $0-40$ & $0.61 \pm 0.10$ & $7.1 \pm 0.1$ \\
& $40-60$ & $0.36 \pm 0.05$ & $7.2 \pm 0.2$ \\
\hline
\end{tabular}

In the control and chiseling options of the field experiment, the dry residue in the $0-40 \mathrm{~cm}$ layer was about $0.1 \%$, and $\mathrm{pH}$ was about 7.4 . In the PTN -40 option, the dry residue and $\mathrm{pH}$ in the $0-40 \mathrm{~cm}$ soil layer were a little bit less than that in the control and chiseling options. After PMS-70 intra-soil milling, the dry residue was almost the same as the PTN-40 option, and pH figures reduced noticeably in the $0-40 \mathrm{~cm}$ soil layer. In the $40-60 \mathrm{~cm}$ soil layer, the dry residue and $\mathrm{pH}$ were rather high in the control option. These figures were the same after chiseling. In the PTN-40 option, the values of the dry residue and $\mathrm{pH}$ were less than that in the control and chiseling options. The PMS-70 intra-soil milling provided a noticeable reduction in the soil dry residue and $\mathrm{pH}$ in the 40-60 layer.

\subsection{Soil Physicochemical Properties after Different Options of Mechanical Treatment}

The content of absorbed $\mathrm{Na}^{+}$in solonetz was about $18-20 \%$ of CEC in the control option. The figures were the same after chiseling. The absorbed $\mathrm{Na}^{+}$content value was of $14-16 \% 30-40$ years after PTN-40 plowing. The content of absorbed $\mathrm{Na}^{+}$was $10-12 \%$ of CEC 30-40 years after PMS-70 soil processing.

\subsection{Soil Organic Matter after Different Options of Mechanical Treatment}

In the control option (standard agriculture), the SOM content (Table 8) was less than that compared to the natural Kastanozem [15].

The SOM content after chiseling was a little bit higher in the period of 3-4 years after the beginning of the experiment, but later on, this content stabilized back to the mean standard agriculture level [45]. The SOM content was higher after PTN-40 plowing compared to the control option. After PMS-70 treatment, the SOM content increased. Soil aggregation after PMS-70 intra-soil milling suited the root system architecture scale, and stabilized the soil geophysical system, both biologically and mechanically. This provided a preferential development of soil biota, plant roots, and a higher norm of SOM synthesis. 
Table 8. Soil organic matter content after different options of mechanical treatment.

\begin{tabular}{ccc}
\hline Soil Processing & Depth, cm & SOM, \% \\
\hline 2019 & & \\
\hline Moldboard plowing, depth $22 \mathrm{~cm}$ (control) & $0-20$ & $2.0 \pm 0.5$ \\
& $20-40$ & $1.3 \pm 0.3$ \\
\hline \multirow{2}{*}{ Chiseling, depth $35 \mathrm{~cm}$} & $0-20$ & $2.1 \pm 0.6$ \\
& $20-40$ & $1.3 \pm 0.3$ \\
\hline \multirow{2}{*}{ Three tier soil tillage PTN-40, depth $45 \mathrm{~cm}$} & $0-20$ & $2.2 \pm 0.5$ \\
\hline \multirow{2}{*}{ Soil milling PMS-70, layer $20-45 \mathrm{~cm}$} & $20-40$ & $3.3 \pm 0.2$ \\
\hline
\end{tabular}

\subsection{Biometric Parameters of Agrophytocenosis}

The spring barley mean yield accounted for $2.55 \mathrm{t} \mathrm{ha}^{-1}$ in the control option (Table 9).

Table 9. Spring barley yield after different options of soil mechanical treatment.

\begin{tabular}{ccc}
\hline Soil Processing & Yield, $\mathbf{t ~ h a}^{-\mathbf{1}}$ & Yield Increment, $\%$ \\
\hline 2019 & & \\
Moldboard plowing, depth $22 \mathrm{~cm}$ (control) & 2.55 & 0 \\
Chiseling, depth $35 \mathrm{~cm}$ & 2.86 & 23 \\
Three tier soil tillage PTN-40, depth $45 \mathrm{~cm}$ & 3.14 & 53 \\
Soil milling PMS-70, layer $20-45 \mathrm{~cm}$ & 3.90 & \\
LSD 0.05 & 0.32 & \\
\hline
\end{tabular}

The yield increment was unreliable in the chiseling option. After PTN-40 plowing, the yield increment was reliable compared to the control option of the experiment. The PMS-70 intra-soil processing provided a reliable increase in yield compared to other options of the experiment.

\subsubsection{Economy of the Different Options of Soil Mechanical Treatment}

For the economic assessment of technology, our own data and literature sources were used $[17,54]$. The technology life cycle duration estimated as follows: Chisel, 3 years; three-tier plowing, 8 years; and intra-soil milling, 30 years according to the long-term field experiments data.

At the estimated technology life cycle [54]—chisel, 3 years; three-tier plowing, 8 years; intra-soil milling, 30 years-annual technology costs were assessed to be, respectively: Chiseling, \$100 ha ${ }^{-1}$; three tier plowing, $\$ 190 \mathrm{ha}^{-1}$; intra-soil milling, $\$ 410 \mathrm{ha}^{-1}$. The mean yield of spring barley accounted for $2.55 \mathrm{t} \mathrm{ha}^{-1}$ in the control option. The yield increment was 12,23 , and $53 \%$, respectively, in the soil processing options of the experiment. The technology profitability was calculated as: Control option, $21.5 \%$; chisel, $6.9 \%$; threetier plowing, $15.6 \%$; and intra-soil milling, $45.6 \%$ in the life cycle. Calculations fulfilled the example of the spring barley. An economic assessment of technology showed the applicability and economically valuable result of intra-soil milling technology [41].

\subsection{Intra-Soil Milling Machine New Technical Solution}

The PMS-70 design comprises the chisel for preliminary soil loosening 2 and the passive ripper 5 (Figure 3). These parts of the machine caused high traction resistance, which was a drawback of the PMS-70 design [55]. Concerning this fact, projecting the new intra-soil processing machine, we applied a heuristic nonstandard approach to synthesize the device mechanical system (Figure 8). The goal was to maintain the benefits of past design while increasing the reliability of the device, reducing the cost of intra-soil processing, and provide efficient land-use. 


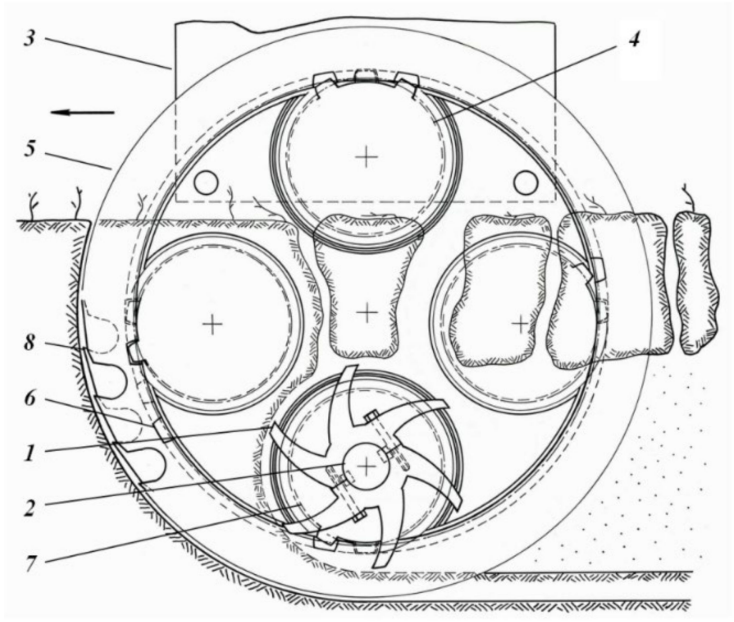

(a)

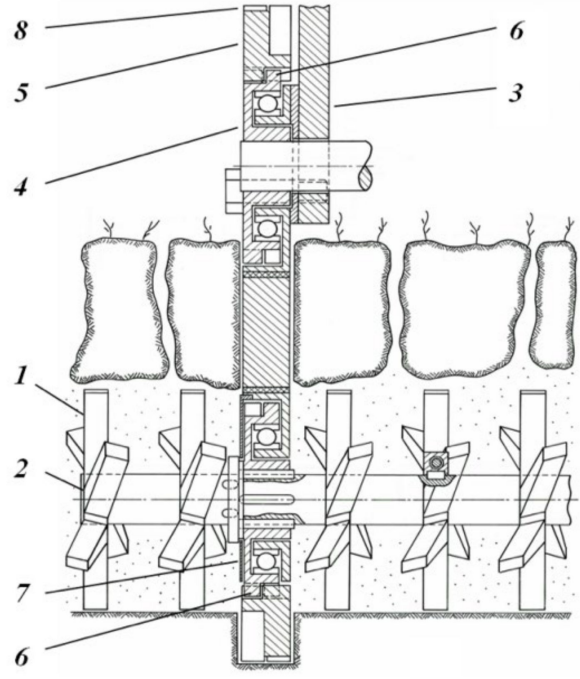

(b)

Figure 8. Intra-soil milling machine PMS-280, (a) side view, (b) front view. Mills 1; shaft 2; frame 3; driving gear 4; ring cogwheel 5; internal gearing 6; driven gear 7; external cutter 8.

The heuristic essence of the new device is the drive unit system 4-8 design. This system moves along the slit without traction resistance [56]. The new intra-soil milling PMS-280 device (Figure 8) comprises the mills 1, shaft 2, frame 3, driving gear 4 ring cogwheel 5, internal gearings 6 , driven gear 7 , and external cutters 8 .

\section{Discussion}

\subsection{Soil Geophysical Properties}

Table 1 data showed that the aggregates composition of the Kastanozem Solonetz is inappropriate for the SOM formation and plant roots growth. This hinders the sustainable evolution of the soil. The need for the Kastanozem Solonetz improvement is obvious.

For the Kastanozem Solonetz amelioration, intra-soil milling of the soil illuvial horizon has been developed [36]. The soil aggregate composition after intra-soil milling (Table 2) showed that the four-, five-, and six-milling cutters ensured the soil illuvial horizon and transitional horizon crushing and mixing, providing a fine aggregate composition of the soil.

In the field experiment, the soil geophysical structure (Table 3) was unsatisfactory for the plat growth after moldboard and soil chiseling. The initial vertical differentiation of the solonetz remained the same after standard moldboard plowing and chiseling. After chiseling, the effect of soil loosening was lost in the period of three-four years [45].

After three-tier plowing, some mixing of the soil layers provided better soil structure compared to the control option of the experiment. The soil loosening effect of the three-tier PTN-40 was higher compared to the moldboard plowing and the soil chiseling. The large blocks of the illuvial horizon (Figure 6 to the left) and transitional horizon (to the right) remained intact until now in this option of the experiment. These large structural blocks hinder soil improvement. To a great extent, the plant roots developed in the vertical cracks between the soil blocks.

The PMS-70 intra-soil processing provided multiple occasions of intensive crumbling and mixing of the illuvial horizon and transitional horizon aggregates in the treated $20-45 \mathrm{~cm}$ layer (Table 3 ). The content of the artificial aggregate particle fraction of 1-3 mm size in the illuvial soil horizon was high, compared to other options of the experiment.

The operating mode of the milling ripper device was full immersion into the soil. This prevented the shortcoming of the surface soil milling machines because the upper horizon position of the soil in the soil profile remained intact. Moreover, the processing energy 
consumption was reduced compared to the surface soil milling machines since its value is proportional to the diameter of the milling cutter.

PMS-70 mills crushed the initial soil aggregates providing a goal hierarchy of the soil porous media fine aggregates. The high content of artificial aggregate particle fraction of 1-3 mm size in the illuvial soil horizon after PMS-70 is a significant result for the optimal evolution of soil. This provides priority roots and biota development, synthesis, conservation, and functioning of SOM in the rhizosphere. After processing, the aggregates $>10 \mathrm{~mm}$ size disaggregate to the smaller size under the increased influence of water, the root system, and geological weathering. The intra-soil milling helps to open the dead-end soil pores for root development and nutrition. The SOM was involved in the active soil biological process after intra-soil milling to a higher degree compared to the standard plowing systems.

The result of intra-soil milling suits the aim of the soil dispersed and aggregated structure formation in focus of the soil biological process promotion compared to the moldboard plowing, chiseling, and three-tier plowing.

\subsubsection{Soil Bulk Density}

With respect to the Table 4 data, the soil bulk density after moldboard plowing exceeded the $1.35 \mathrm{t} \mathrm{m}^{-3}$ value, which is critical for the plant growth on the Kastanozem [15]. Almost the same result was observed after chiseling. The soil bulk density was slightly less after PTN-40 plowing.

Soil bulk density was excessive after moldboard plowing, chiseling, and PTN-40 plowing. In the zone of Kastanozem, the standard adverse effects of the periodic excessive soil moisture are soil peptization, soil superdispersity, soil fusing, and subsequent soil compaction [57]. These well-known effects manifested in results of standard agronomy practice and standard soil amelioration practice because of an unstable mineralogical composition of Kastanozem [58], influencing instability of the soil structure and architecture, and causing high soil bulk density.

After the PMS-70 option of the experiment, the bulk density of soil is a prerequisite for the soil multilevel architecture because intra-soil milling produced a fundamentally new soil geophysical structure. The long-term soil bulk density figures were optimal for plant growth. The artificial weathering front moved deeper into the soil drastically. The intra-soil milling increased the artificial aggregation and reinforcement of the soil's fine particles with carbonates, roots, and SOM, and reduced the standard adverse effects of periodical excessive moisturizing and soil compaction.

Compared to the standard plowing options, the new geophysical soil structure after PMS-70 soil processing did not lose its strength (or lost it to a small extent) under the influence of the water gravitational downward flux to the vadose zone under the impact of precipitation. This is because the volume of soil porous media, which accepts the water, is greater after soil processing with PMS-70. Thus, a shorter period of excessive water impacts the soil aggregates. We share the point of view of I.M. Young et al. [59], supported by P. Baveye [60] that a functional quantification of soil structure is much more complicated compared to the standard result of aggregates' determination on the set of sieves (Tables 1-3). The process of aggregation does not necessarily imply the development of distinct separated soil aggregates within the soil profile. The existence of aggregates in situ is probably a sequence of the disaggregation-aggregation stages. The intra-soil milling provides better control of the disaggregation-aggregation equilibrium than the conventional soil plowing technology ensures.

\subsection{Morphology of Soil and Development of Roots}

The spread of rhizosphere in the $0-20 \mathrm{~cm}$ topsoil layer was unsatisfactory for plant growth in the control option (Table 5). Differentiation of the root system corresponded to the unfavorable morphological arrangement of the soil profile (Figure 5). The border in the soil between eluvial (in agriculture-plowing layer) and illuvial horizons was whitish due 
to the soil mass transformation under the influence of solonetzic pedogenesis. Almost the same was observed after chiseling. Here, the rhizosphere spread down to a $35 \mathrm{~cm}$ depth, but only in the soil crevices along the trace of the chisel.

After standard tillage and chiseling, the soil morphological conditions, geophysical structure, and aggregate composition did not provide the SOM synthesis, soil productivity, and sustainable evolution of the soil as well.

After three-tier plowing (Table 5, Figure 6), in the morphological structure of the soil profile, there were many blocks of the soil illuvial horizon in the soil surface layer. At the same time, a large portion of aggregates from the upper soil horizon poured down the soil profile.

The soil loosening effect of the three-tier PTN-40 was higher than that after the moldboard plowing and soil chiseling. The roots and soil biota were spread throughout the local comfort zones of the soil profile.

The prerequisites were much better for the stimulation of soil microbiota, the rhizosphere, and plants after PMS-70 $20-45 \mathrm{~cm}$ intra-soil processing (Table 5, Figure 7). The soil acquired a homogeneous fine macro-aggregate structure throughout the entire soil profile $0-45 \mathrm{~cm}$ layer. In a period of 30-40 years after PMS-70, there were no morphological signs of the solonetzic pedogenesis restoration. The rhizosphere penetrates freely down to a depth of about $40-45 \mathrm{~cm}$. Plant roots spread evenly through the processed soil profile.

The root system formed a stable mechanical framework that retained the new soil structure favorable for plants after PMS-70 treatment. This prerequisite provided a biological stabilization of the soil medium $\mathrm{pH}$ value close to 7 . The soil multilevel dispersed fine macro-aggregate system was stable (Section 4.1.1).

The soil after PMS-70 20-45 cm intra-soil processing has a uniform darker coloration and is occupied by the rhizosphere (Figure 7). This provides a prerequisite for the long-term successful soil biological process, reliable SOM turnover, and higher soil productivity [61].

\subsection{Soil Moisture in Field Experiment}

The soil moisture regime repeated the known natural regularities of the dry steppe in the control option of the experiment (Table 6). The rate of moisture penetration into the soil was weak. The water redistributes locally over the soil surface between the Kastanozem complex components and evaporates from the soil surface in a noticeable quantity [33,41]. The soil moisture regime improved only slightly in the first 3-4 years after chiseling [45]. After the PTN-40, water penetrates the soil's deeper horizons prematurely into the soil zones to which the soil upper humus layer fragments strewed down during the soil plowing. Overall, the soil moisture regime after moldboard plowing, chiseling, and three-tier plowing corresponds a regional pattern.

After PMS-70 processing, a loose and homogeneous soil layer provided a diverse soil solution flux from fine soil macro-aggregates to the rhizosphere. The last had a larger area of surface contact with the moist soil. Thus, the plants spent less energy and nutrients to get the soil solution from the soil compared with standard technologies. The plant redistributed saved energy for the sake of rhizosphere development and carbon reversible sequestration in the SOM, as well as for the aboveground biomass formation.

\subsection{Soil Salinity and Physicochemical Properties}

Soil salinity did not change under the standard agronomy practice in the control option in the period of the experiment (Table 7). Thirty years after the experiment began, the dry residue was not high in the $0-40 \mathrm{~cm}$ soil layer in the experiment. The dry residue in the $40-60 \mathrm{~cm}$ soil layer was rather high in the control and chisel options. After PTN-40, the dry residue in the 40-60 $\mathrm{cm}$ soil layer was reduced compared to the control option, and the chisel as well. After PMS-70, the dry residue in the 40-60 cm soil layer was reduced almost twice compared to the control and chisel options, and 30\% compared to the PTN -40 option.

The change of the soil moisture regime was insignificant and short-term after chiseling. The salt regime of soil did not change after chiseling as well. There was no sufficient internal 
surface for the developed soil-water-gas interfaces inside the undestroyed soil blocks for leaching of the salts and product of SAC exchange reactions after PTN-40. The soil salt properties were better after PTN-40 compared to standard agronomy and chiseling but remained close to that of the natural properties on the Kastanozem complex.

The soil desalination was higher after PMS-70 compared to other options of the experiment. The downward shift of the upper boundary of salt horizon was obvious. This dynamic of the salt balance was a consequence of the long-term favorable moisture regime in the soil profile of the Kastanozem complex, provided by the PMS-70.

The content of absorbed $\mathrm{Na}^{+}$in the CEC in solonetz was rather high in the control option. This is a standard unfavorable result of the conventional agronomy practice. The same adverse result was observed after chiseling. After PTN-40 plowing, the content of absorbed $\mathrm{Na}^{+}$in the CEC in solonetz was reduced compared to the control option and the option of chiseling as well. Soil amelioration proceeds on the full scale after PMS-70 processing. The readily soluble salts actively leached due to the transfer of sulfates and carbonates from the transition horizon to the illuvial horizon, and phyto-amelioration. The conditions were conducive for the exchange reactions in the SAC. The content of absorbed $\mathrm{Na}^{+}$in CEC was reduced compared to the control option, the option of chisel, and $25 \%$ compared to the PTN-40 plowing option. Artificial fine soil aggregates were a comfortable substrate for the development of the root system and biota after PMS-70 processing.

\subsection{SOM in Field Experiment}

The humus content is relatively small, about $3.0 \%$, in a virgin soil of Kastanozem complex [33]. The SOM content at the standard agriculture is lower than that in the natural soil (Table 8). This is a lack of the current standard moldboard plowing and chisel technologies. The SOM content was higher after PTN-40 plowing. Some part of the organic material was lost deeper into the soil and mineralized or subjected to sedimentation between the blocks of illuvial and transition horizons.

The content of the accessible form of soil nutrients was higher after the PMS-70 treatment compared to other options of the experiment. The statement is justified concerning the SOM increment. After PMS-70 treatment, the SOM content increased to $3.3 \%$ in the $0-20 \mathrm{~cm}$ soil layer and to $2.1 \%$ in the $20-40 \mathrm{~cm}$ layer. Soil aggregation suited the root system architecture scale, and stabilized the soil geophysical system, both biologically and mechanically. As a result, the root system obtained better prerequisites for carbon dioxide release into the soil solution. The carbon dioxide loss from soil was reduced correspondingly to a fine soil aggregate composition. The multilevel soil aggregates architecture reduced the rate of carbon dioxide release from the soil to the atmosphere. The conditions of manifestation of the carbonic acid amphoteric properties in soil solution were improved. The soil $\mathrm{pH}$ value was about 7.1-7.3.

The improved SOM regime reveals the function of natural organic compounds in the soil solution as indicators of soil quality and increased biological productivity [62]. The loss of biological matter from soil was reduced [63].

\subsection{Yield of Agrophytocenosis and Technology Economical Assessment}

The data for yield in the experiment (Table 9) showed a decisive preference of the PMS70 intra-soil milling before the moldboard, chiseling, and three-tier plowing by PTN-40. The increment of spring barley yield was up to 53\% in the PMS-70 option. The profitability of the intra-soil milling technology was 2.9 to 6.6 times higher compared to other options of the field experiment.

\subsection{New Intra-Soil Device Development}

The new PMS-280 device (Figure 8) retains the principle of intra-soil processing by the mills 1 installed on the horizontal shaft 2 . The heuristic entity of the new device is a design of the drive unit system 4-8 [64]. The external cutters 8 on the ring cogwheel 5 performs a slit in the soil. The system 4-8 moves along the slit transmitting the torque to the milling 
tool positioned inside the geophysical solid media. Compared to the former developments, the new design reduces the traction resistance of the machine by 5 , the reliability increases by $80 \%$, and the energy cost is 2 times lower. We have a series of related patents [65-69]. The North Caucasus State Zonal Machine Test Station (Zernograd), which is widely known and authoritative in the world, verified new intra-soil device rotor drive (Figure 9) [70].

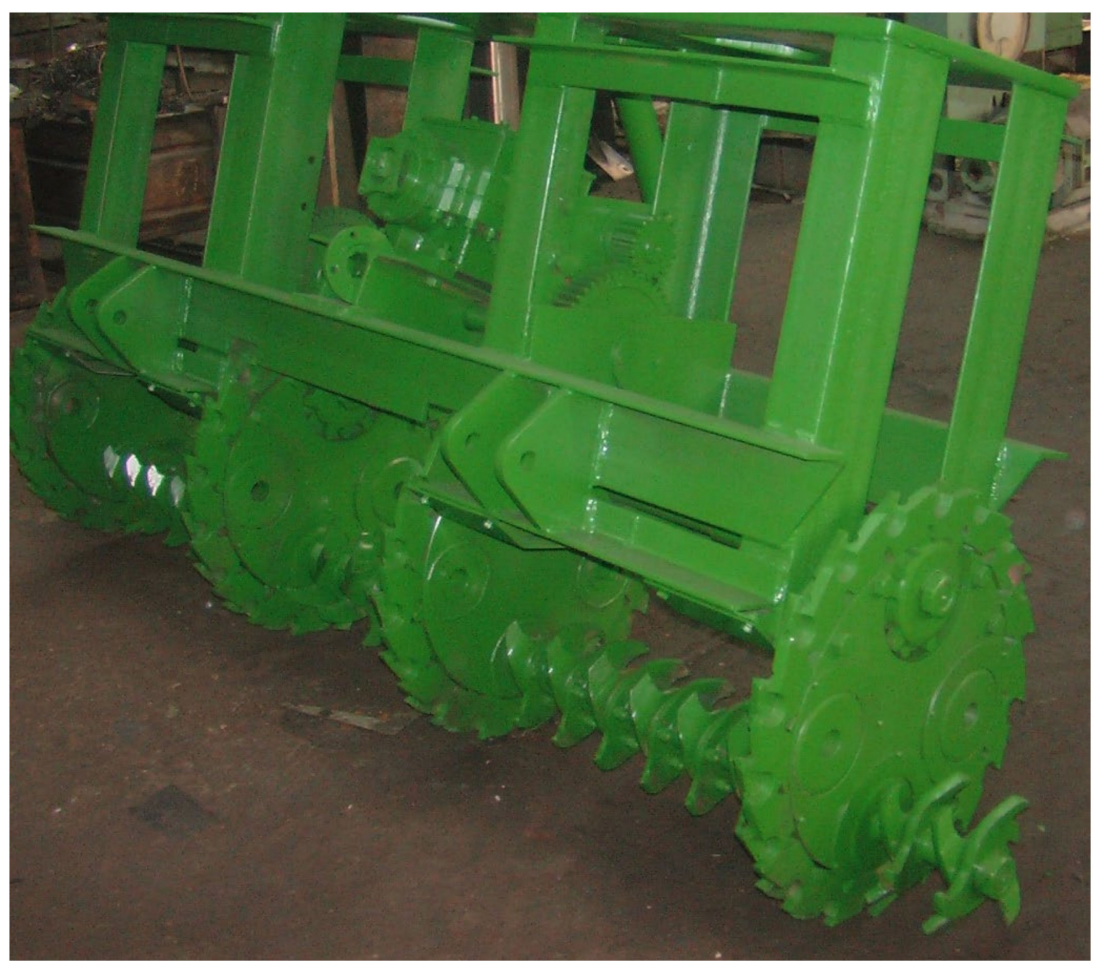

Figure 9. Intra-soil milling machine PMS-280.

The fulfilled geophysical, biological, technical, and economical assessments of the BGT $^{*}$ methodology are the basis of the positive forecast for intra-soil milling practical application. The formation, accumulation, stability, and transformation of SOM into nutrients will provide long-term sustainable evolution of the highly fertile healthy soil $[9,71]$.

New technology is a condition of the SOM stabilizing and enriched biological turnover. The technology provides the priority of the rhizosphere expansion, formation, and stabilization of soil aggregates. Better conditions of plant development ensure natural prerequisites for the suppression of phytopathogen [31]. The soil biological productivity becomes higher [23,72]. This eases the conflict "Biosphere-Technology" [73]. Higher biosphere biological production is a buffer of the climate system stability $[69,74]$. The new design of the intra-soil milling machine provides five times less traction resistance and $80 \%$ increased reliability, halving energy costs.

\section{Conclusions}

In the Kastanozem complex of the dry steppe, the morphological, geophysical, chemical, physicochemical properties, SOM, root development, yield, and agro-economic efficacy were studied. The standard moldboard plowing, chiseling, and three-tier tillage are incapable of providing the formation of the stable soil aggregate system for plant growth and productivity. The soil bulk density was high and increased with depth. The soil aggregates remained impermeable to roots. The moldboard plowing, chiseling, and three-tier tillage showed a short-term effect on the soil geophysical disperse aggregate structure.

The transcendental BGT* methodology developed of the illuvial horizon and transitional horizon intra-soil milling, focused on a stable soil structure for plant growth and productivity. Intra-soil milling cutters were developed and tested. The PMS-70 machine 
was developed for intra-soil milling of the soil layer $20-45 \mathrm{~cm}$. The PMS-70 was tested in the field experiment in the Kastanozem complex of the dry steppe. The field experiment revealed that PMS-70 ensures a long-term stable multilevel fine aggregate $1-3 \mathrm{~mm}$ sized system in the processed soil layer, and indirectly improves the geophysical properties of the soil upper layer. Intra-soil milling provides an unimpeded spread of the rhizosphere in the soil layer $0-45 \mathrm{~cm}$. Soil water content increased. Conditions for plant nutrition improved. Soil salinization was reduced and the $\mathrm{pH}$ value was close to 7.0. SOM content increased. Compared to moldboard plowing, chiseling, and three-tier tillage, the PMS-70 intra-soil processing ensured better plant growth and a reliable increase in yield. The newly developed intra-soil milling machine PMS-280 reduces traction resistance and provides higher reliability. The $\mathrm{BGT}^{*}$ transcendental methodology of the illuvial horizon and the transitional horizon intra-soil milling is an important prerequisite to improve the soil-biological process and to have the higher land use efficacy.

\section{Patents}

1. Gyachev L.V., Sharshak V.K. The working body of the soil mill. Patent USSR No. 506339. IPC A01B35/20. Application 1994508, 01/30.1974. Published 03/15/1976. Bull. 10.

2. Kalinichenko V.P. Patent RU No 2273120 C2. Rotary subsoil ripper. IPC A01B 33/02. Application 2004111564, 04/16/04. Published 04/10/2006. Bull. 10. https:/ / new.fips.r u/Archive/PAT/2006FULL/2006.04.10/DOC/RUNWC2/000/000/002/273/120/D OCUMENT.PDF, accessed on 6 July 2021.

3. Matishov G.G., Kalinichenko V.P., Sharshakov V.K., Illarionov V.V., Ladan E.P., Genev E.D., Mishchenko N.A., Endovickii A.P., Chernenko V.V., Sukovatov V.A., Ilyina L.P., A.V. Zinchenko. Patent RU No 2438293. Method of long-term productivity management of steppes biogeosystem of southern Russia. IPC A01B 13/14 (2010.01) A01V 39/08 (2010.01). Application 2010116534/20, 04/26/2010. Published, 01/10/2012. Bull. 1. https: / / new.fips.ru/Archive/PAT/2012FULL/2012.01.10/DOC/RUNWC 1/000/000/002/438/293/DOCUMENT.PDF, accessed on 6 July 2021.

4. Kalinichenko V.P., Sharshak V.K., Illarionov V.V., Ladan E.P., Genev E.D., Gromyko E.V., Zinchenko V.E., Balakay G.T., Radevich E.V., Balakay N.I., Larin S.V., Ivanenko A.A. Patent RU No 2444874 C2. Device for loosening the inner layer of soil. IPC A01B 13/16 (2006.01), A01B 33/02 (2006.01). Application 2010120154/13, 05/19/2010. Published, 03/20/2012. Bull. 8. https:/ / new.fips.ru/Archive/PAT/2012FULL/2012 .03.20/DOC/RUNWC2/000/000/002/444/874/DOCUMENT.PDF, accessed on 6 July 2021.

5. Kalinichenko V.P., Sharshak V.K., Zinchenko V.E., Ladan E.P., Illarionov V.V., Genev E.D., Chernenko V.V., Endovitsky A.P., Il'in V.B., Larin S.V., Shatohin S.A. Patent RU No 2454846 C2. Device for subsurface rotational loosening. IPC A01B 13/16 (2006.01) A01B 33/02 (2006.01). Application 2010137717/21, 09/09/2010. Published 07/10.2012. Bull. 19. https: / / new.fips.ru/Archive/PAT/2012FULL/2012.07.10/DOC/RUNWC 2/000/000/002/454/846/DOCUMENT.PDF, accessed on 6 July 2021.

6. Kalinitchenko V.P. Patent RU No 2475005 C2. Device for rotary subsurface tillage. IPC A01V IPC 33/02 (2006.01) A01V 49/02 (2006.01). Application 2010133702/17, 11/08/10. Published 20/02/2013. Bull 5. https://new.fips.ru/Archive/PAT/201 3FULL/2013.02.20/DOC/RUNWC2/000/000/002/475/005/DOCUMENT.PDF, accessed on 6 July 2021.

7. Kalinichenko V.P., Glinushkin A.P., Sokolov M.S., Budynkov N.I., Zinchenko V.E., Chernenko V.V., Kozyrev S.G. Patent RU №2720634 C1. The method of intra-soil introducing of biological product. MPC A01G 25/06 (2006.01) A01C 23/02 (2006.01), SPC A01G 25/06 (2020.02) A01C 23/02 (2020.02). Application 2019117310/033090, 06/04/2019. Published 05/12/2020. Bul. 14. https://new.fips.ru/ofpstorage/Doc/IZ PM/RUNWC1/000/000/002/720/634/\%D0\%98\%D0\%97-02720634-00001/docume nt.pdf, accessed on 6 July 2021. 
Author Contributions: All authors contributed to the study conception and design. Material preparation, sampling, and data collection were performed by E.P.L., S.N.S., V.V.C., L.P.I. and A.I.B.; statistical analysis was carried out by S.S.M., V.M.K., A.A.B. and E.M.A.; supervision of all study was performed by A.P.G., V.K.S. and T.M.M.; the first draft of the manuscript was written by V.P.K. and all authors commented on previous versions of the manuscript. All authors have read and agreed to the published version of the manuscript.

Funding: The research was financially supported by the Ministry of Science and Higher Education of the Russian Federation (project no. 0852-2020-0029). The analytics performed on the equipment of the Centers for Collective Use of Southern Federal University "High Technology" and "Biotechnology, Biomedical, and Environmental Monitoring".

Institutional Review Board Statement: Not applicable.

Informed Consent Statement: Not applicable.

Data Availability Statement: The data supporting reported results can be given by the authors on request.

Conflicts of Interest: The authors declare no conflict of interest. The funders had no role in the design of the study; in the collection, analyses, or interpretation of data; in the writing of the manuscript, or in the decision to publish the results.

\section{References}

1. Jat, H.S.; Choudhary, M.; Datta, A.; Yadav, A.K.; Meena, M.D.; Devi, R.; Gathala, M.K.; Jat, M.L.; McDonald, A.; Sharma, P.C. Temporal changes in soil microbial properties and nutrient dynamics under climate smart agriculture practices. Soil Till. Res. 2020, 199, 104595. [CrossRef] [PubMed]

2. Jensen, J.L.; Schjønning, P.; Watts, C.W.; Christensen, B.T.; Munkholm, L.J. Short-term changes in soil pore size distribution: Impact of land use. Soil Till. Res. 2020, 199, 104597. [CrossRef]

3. Granstrand, O.; Holgersson, M. Innovation ecosystems: A conceptual review and a new definition. Technovation 2020, 90-91, 102098. [CrossRef]

4. Grandjean, G.; Cousin, I.; Seger, M.; Thiesson, J.; Lambot, S.; Van Wesemael, B.; Stevens, A.; Samyn, K.; Bitri, A.; Bernardie, S. From Geophysical Parameters to Soil Characteristics. Report N BRGM/FP7-DIGISOIL-D2.1, 2009, 52p. Available online: https:/ / hal.inrae.fr/hal-02824942 (accessed on 6 July 2021).

5. Juarez, S.; Nunan, N.; Duday, A.-C.; Pouteau, V.; Schmidt, S.; Hapca, S.; Falconer, R.; Otten, W.; Chenu, C. Effects of different soil structures on the decomposition of native and added organic carbon. Eur. J. Soil Biol. 2013, 58, 81-90. [CrossRef]

6. De Gryze, S.; Jassogne, L.; Six, J.; Bossuyt, H.; Wevers, M.; Merckx, R. Pore structure changes during decomposition of fresh residue: X-ray tomography analysis. Geoderma 2006, 134, 82-96. [CrossRef]

7. Shein, E.V.; Skvortsova, E.B.; Abrosimov, K.N. Tomographic studies of the soil pore space in swelling and shrinkage processes. In Abstract Book, Proceedings of the 9th International Soil Science Congress on "The Soul of Soil and Civilization", Antalya, Turkey, 14-16 October 2014; Soil Science of Turkey Cooperation with Federation of Eurasian Soil Science Societies: Ankara, Turkey, $2014 ;$ p. 107. Available online: https: / / www.elibrary.ru/item.asp?id=23535847 (accessed on 6 July 2021).

8. Lisetskii, F.N.; Goleusov, P.V.; Stolba, V.F. Modeling of the evolution of steppe chernozems and development of the method of pedogenetic chronology. Eurasian Soil Sci. 2016, 49, 846-858. [CrossRef]

9. Van Mansvelt, J.-D. Soil Fertility in Agriculture: Russia-Western Europe-USA: In the Past and Today. Biogeosyst. Tech. 2017, 4, 220-231. [CrossRef]

10. Deep Ripping for Soil Compaction. Available online: https://www.agric.wa.gov.au/soil-compaction/deep-ripping-soil-compac tion (accessed on 18 June 2020).

11. Management of Solonetzic Soils. Available online: https://www1.agric.gov.ab.ca/\$department/deptdocs.nsf/all/agdex166 (accessed on 18 June 2020).

12. Kataoka, T.; Shibusawa, S. Soil-blade dynamics in reverse-rotational rotary tillage. J. Terramechanics 2002, 39, 95-113. [CrossRef]

13. Makange, N.R.; Tiwari, V.K. Effect of Horizontal and Vertical Axis Rotavators on Soil Physical Properties and Energy Requirement. Trends Biosci. 2015, 8, 3225-3234.

14. Effect of Horizontal and Vertical Axis Rotavators on Soil Physical Properties and Energy Requirement Print. ISSN 0974-8. Available online: https:/ /www.researchgate.net/publication/281279756_Effect_of_Horizontal_and_Vertical_Axis_Rotavator s_on_Soil_Physical_Properties_and_Energy_Requirement (accessed on 18 June 2020).

15. Minkin, M.; Ladan, E.; Bondarenko, T. Sub-soil milling reclamation treatment. Int. Agric. J. 1978, 5, 92-94.

16. Ahmadi, H.; Mollazade, K. Effect of Plowing Depth and Soil Moisture Content on Reduced Secondary Tillage, Agricultural Engineering International. The CIGR J. 2009, XI, 1-9. Available online: http://www.cigrjournal.org/index.php/Ejounral/article /view/1195 (accessed on 6 July 2021). 
17. Soil Management and Health. Upper Midwest Tillage Guide. Tillage Implements, Purpose and Ideal Use. Available online: https:/ / extension.umn.edu/soil-and-water/soil-management-and-health (accessed on 18 June 2020).

18. Vogel, L.E.; Makowski, D.; Garnier, P.; Vieublé-Gonod, L.; Coquet, Y.; Raynaud, X.; Nunan, N.; Chenu, C.; Falconer, R.; Pot, V. Modeling the effect of soil meso-and macropores topology on the biodegradation of a soluble carbon substrate. Adv. Water Resour. 2015, 83, 123-136. [CrossRef]

19. Sarker, J.R.; Singh, B.P.; Dougherty, W.J.; Fang, Y.U.; Badgery, W.; Hoyle, F.C.; Dalal, R.C.; Cowie, A.L. Impact of agricultural management practices on the nutrient supply potential of soil organic matter under long-term farming systems. Soil Till. Res. 2018, 175, 71-81. [CrossRef]

20. Lehman, R.M.; Cambardella, C.A.; Stott, D.E.; Acosta-Martinez, V.; Manter, D.K.; Buyer, J.S.; Maul, J.E.; Smith, J.L.; Collins, H.P.; Halvorson, J.J.; et al. Understanding and Enhancing Soil Biological Health: The Solution for Reversing Soil Degradation. Sustainability 2015, 7, 988-1027. [CrossRef]

21. Schneider, F.; Don, A.; Hennings, I.; Schmittmann, O.; Seidel, S.J. The effect of deep tillage on crop yield-What do we really know? Review. Soil Till. Res. 2017, 174, 193-204. [CrossRef]

22. Keesstra, S.D.; Bouma, J.; Wallinga, J.; Tittonell, P.; Smith, P.; Cerdà, A.; Montanarella, L.; Quinton, J.N.; Pachepsky, Y.; van der Putten, W.H.; et al. The significance of soils and soil science towards realization of the United Nations Sustainable Development Goals. Soil 2016, 2, 111-128. [CrossRef]

23. Kalinitchenko, V.P.; Glinushkin, A.; Sokolov, M.; Batukaev, A.; Minkina, T.; Zinchenko, V.; Chernenko, V.; Startsev, V.; Mandzhieva, S.; Sushkova, S.; et al. Biogeosystem Technique for Healthy Soil, Water and Environment. In Proceedings of the ACS Fall 2019 National Meeting and Exposition, Chemistry and Water, San Diego, CA, USA, 25-29 August 2019.

24. Ani, O.A.; Uzoejinwa, B.B.; Ezeama, A.O.; Onwualu, A.P.; Ugwu, S.N.; Ohagwu, C.J. Overview of soil-machine interaction studies in soil bins. Soil Till. Res. 2018, 175, 13-27. [CrossRef]

25. Neuman, J. Soil Organic Matter Maintenance in No-Till and Crop Rotation Management Systems. Soil Organic Matter. Reference Module in Earth Systems and Environmental Sciences 2017. Available online: https://www.mdpi.com/2076-3417/10/7/2571/h tm (accessed on 6 July 2021).

26. Totsche, K.U.; Amelung, W.; Gerzabek, M.H.; Guggenberger, G.; Klumpp, E.; Knief, C.; Lehndorff, E.; Mikutta, R.; Peth, S.; Prechtel, A.; et al. Microaggregates in soils. Review Article. Special Issue: Methodological advances in studying the soil-plant-atmosphere gas exchange. J. Plant Nutr. Soil Sci. 2018, 181, 104-136. [CrossRef]

27. Lin, H. Chapter 2-Understanding Soil Architecture and Its Functional Manifestation across Scales. Part I: Overviews and Fundamentals. Hydropedology 2012, 41-74. Available online: https://pennstate.pure.elsevier.com/en/publications/understandin g-soil-architecture-and-its-functional-manifestation- (accessed on 6 July 2021).

28. Swidsinski, A. The colonic bioreactor-A forerunner model for future biotechnology (function, role, products \& management). In Proceedings of the Fifth International Conference of CIS IHSS on Humic Innovative Technologies: Humic Substances and living Systems, Moscow, Russia, 19-23 October 2019. [CrossRef]

29. Kalinichenko, V. Biogeosystem Technique as a problem. Biogeosyst. Tech. 2014, 1, 4-19. [CrossRef]

30. Kalinitchenko, V.P. Optimizing the matter flow in biosphere and the climate of the Earth at the stage of technogenesis by methods of biogeosystem technique (problem-analytical review). Int. J. Environ. Probl. 2016, 4, 99-130.

31. Glinushkin, A.P.; Kudeyarov, V.N.; Sokolov, M.S.; Zinchenko, V.E.; Chernenko, V.V. Nature-Similar Technologies of the Biogeosystem Technique in Solving a Global Social and Environmental Problem. Biogeosyst. Tech. 2018, 5, 159-196. [CrossRef]

32. Panov, V.D.; Lurie, P.M.; Larionov, Y.A. Climate of the Rostov Region Yesterday, Today, Tomorrow; Donskoy Publishing House LLC: Rostov-on-Don, Russia, 2006; p. 488.

33. Sadimenko, P.A. Soils of Southeastern Districts of Rostov Region; RSU Publishing: Rostov-on-Don, Russia, 1966 ; p. 127.

34. IUSS Working Group WRB. World Reference Base for Soil Resources 2014, Update 2015. International Soil Classification System for Naming Soils and Creating Legends for Soil Maps. World Soil Resources Reports No. 106. 2015. Available online: http: / / www.fao.org/3/i3794en/I3794en.pdf (accessed on 6 July 2021).

35. Egorov, V.V.; Fridland, V.M.; Ivanova, E.N.; Rozov, N.N. Classification and Diagnostics of Soils of the Soviet Union; Kolos: Moscow, Russia, 1977; p. 223.

36. Sharshak, V.K. Sub-Soil Milling Machines. Design Recommendations; Southern Research Institute of Hydraulic Engineering and Land Reclamation: Novocherkassk, Russia, 1975; p. 74.

37. Sharshak, V.K. Evaluation of machines and tools for basic processing of alkaline soils. Mech. Electrif. Agric. 1987, 3, 17-19.

38. Carter, M.R.; Gregorich, E.G. Soil Sampling and Methods of Analysis, 2nd ed.; CRC Press: Boca Raton, FL, USA, 2007.

39. Klute, A. Methods of Soil Analysis. Part 1. Physical and Mineralogical Methods, 2nd ed.; Soil Science Society of America: Madison, WI, USA, 1986; p. 1188.

40. Shtiza, A.; Swennen, R. Appropriate sampling strategy and analytical methodology to address contamination by industry. Part 2: Geochemistry and speciation analysis. Open Geosci. 2011, 3, 53-70. [CrossRef]

41. Kalinichenko, V.P.; Sharshak, V.K.; Mironchenko, S.F.; Chernenko, V.V.; Ladan, E.P.; Genev, E.D.; Illarionov, V.V.; Udalov, A.V.; Udalov, V.V.; Kippel, E.V. Changes in the properties of soils in a solonetz soil complex thirty years after reclamation. Eurasian Soil Sci. 2014, 47, 319-333. [CrossRef]

42. Lawrence, P.G.; Roper, W.; Morris, T.F.; Guillard, K. Guiding soil sampling strategies using classical and spatial statistics: A review. Agron. J. 2020, 112, 493-510. [CrossRef] 
43. Kalinitchenko, V.P.; Glinushkin, A.P.; Swidsinski, A.V.; Minkina, T.M.; Andreev, A.G.; Mandzhieva, S.S.; Sushkova, S.N.; Makarenkov, D.A.; Iljina, L.P.; Chernenko, V.V.; et al. Thermodynamic mathematical model of the Kastanozem complex and new principles of sustainable semiarid protective silviculture management. Environ. Res. 2021, 194, 110605. [CrossRef]

44. Nichols, K. Soil Quality Demonstrations and Procedures; USDA-ARS-Northern Great Plains Research Laboratory: Mandan, ND, USA, 2011. Available online: https://www.ars.usda.gov/ARSUserFiles/35170/soil\%20quality\%20demos\%20January\%202011.pdf (accessed on 6 July 2021).

45. Kalinichenko, V.P.; Sharshak, V.K.; Bezuglova, O.S.; Ladan, E.P.; Genev, E.D.; Illarionov, V.V.; Zinchenko, V.E.; Morkovskoi, N.A.; Chernenko, V.V.; Il'ina, L.P. Changes in the Soils of Solonetzic Associations in 30 Years after Their Reclamation with the Use of Moldboard Plowing, Deep Tillage with a Three-Tier Plow, and Deep Rotary Tillage. Eurasian Soil Sci. 2011, 44, 927-938. [CrossRef]

46. Van Genuchten, M.T.; Leij, F.J.; Yates, S.R. The RETC Code for Quantifying the Hydraulic Functions of Unsaturated Soils; US Salinity Lab: Riverside, CA, USA, 1991.

47. De Janvry, A.; Sadoulet, E.; Surix, T. Field Experiments in Developing Country Agriculture. Chapter 5. Handbook of Economic Field Experiments; Elsevier B.V.: Amsterdam, The Netherlands, 2017; Volume 2, pp. 427-466, ISSN 2214-658X. [CrossRef]

48. SW-846 Test Method 9081: Cation-Exchange Capacity of Soils (Sodium Acetate). Available online: https://www.epa.gov/hw-s w846/sw-846-test-method-9081-cation-exchange-capacity-soils-sodium-acetate (accessed on 18 June 2020).

49. Walkley, A.; Black, I.A. An examination of the Degtjareff method for determining soil organic matter, and a proposed modification of the chromic acid titration method. Soil Sci. 1934, 37, 29-38. [CrossRef]

50. Ditzler, C.; Scheffe, K.; Monger, H.C. (Eds.) Soil Science Division Staff. Soil Survey Manual. In USDA Handbook 18; Government Printing Office: Washington, DC, USA, 2017. Available online: https://www.nrcs.usda.gov/wps/portal/nrcs/detail/soils/scien tists / ?cid=nrcs142p2_054262 (accessed on 18 June 2020).

51. Kalinichenko, V.P.; Sharshak, V.K.; Ladan, E.P.; Zarmaev, A.A.; Zinchenko, V.E. Device for rotary intra-soil machining. Bull. Don State Tech. Univ. 2013, 3-4, 41-53.

52. Land reclamation plow ПMС-70 for solonetz processing. North Caucasus Interdisciplinary Territorial Center for Scientific and Technical Information and Propaganda. Fact Sheet 43-73. PC 42442. 02/06/1073. 8 p.

53. Sharshak, V.K.; Ladan, E.P.; Kalinichenko, V.P.; Zinchenko, V.E.; Chernenko, V.V.; Mironchenko, S.F.; Illarionov, V.V.; Genev, E.D.; Kippel, E.V.; Statsko, V.A. Theoretical basis for creating dispersed systems in soils and innovative rotary-milling soil treatment. Sci. J. Russ. Res. Inst. Land Reclam. Probl. 2012, 1, 10-30.

54. Farm Business Management. Department of Agricultural and Consumer Economics • College of Agricultural, Consumer and Environmental Sciences University of Illinois at Urbana-Champaign, Machinery Cost Estimates: Field Operations. Available online: http:/ / www.farmdoc.illinois.edu/manage/machinery/field\%20operations\%202012.pdf (accessed on 18 June 2020).

55. Gyachev, L.V.; Sharshak, V.K. The Working Body of the Soil. Mill. Patent USSR No. 506339, 30 January 1974.

56. Kalinichenko, V.P. Patent RU No 2273120 C2. Rotary Subsoil Ripper. Available online: https://new.fips.ru/Archive/PAT/2006F ULL/2006.04.10/DOC/RUNWC2/000/000/002/273/120/DOCUMENT.PDF (accessed on 6 July 2021).

57. Topunova, I.V.; Prikhodko, V.E.; Sokolova, T.A. Influence of irrigation on the content and mineralogical composition of the clay fraction of the chernozem of the Rostov region (Bagaevsky-Sadkovsky irrigation system). Mosc. Univ. Bulletin. Ser. 17 Soil Sci. 2010, 1, 3-10.

58. Chizhikova, N.P.; Khitrov, N.B.; Tronza, G.E.; Kol'tsov, S.A.; Varlamov, E.B.; Chechetko, E.S.; Churilin, N.A. Mineralogical Composition of Particle-Size Fractions of Solonetzes from the North Crimean Lowland. Eurasian Soil Sci. 2017, 50, 1468-1482. [CrossRef]

59. Young, I.M.; Crawford, J.W.; Rappoldt, C. New methods and models for characterizing structural heterogeneity of soil. Soil Till. Res. 2001, 61, 33-45. [CrossRef]

60. Baveye, P. Comment on "Soil structure and management: A review" by C.J. Bronick and R. Lal. Geoderma 2006, 134, 231-232. [CrossRef]

61. Kalinichenko, V.P.; Sharshak, V.K.; Zinchenko, V.E.; Chernenko, V.V. Long-term change of reclaimed chestnut solonetzic soils after single rotor internal plowing. Bull. Don State Tech. Univ. 2013, 13, 67-75.

62. Shein, E.V.; Kharitonova, G.V.; Milanovsky, E.Y. Aggregation of natural disperse formations: Value of organic matter, soluble salts and diatoms. Biogeosyst. Tech. 2016, 7,77-86. [CrossRef]

63. Batukaev, A.A.; Endovitsky, A.P.; Andreev, A.G.; Kalinichenko, V.P.; Minkina, T.M.; Dikaev, Z.S.; Mandzhieva, S.S.; Sushkova, S.N. Ion association in water solution of soil and vadose zone of chestnut saline solonetz as a driver of terrestrial carbon sink. Solid Earth 2016, 7, 415-423. [CrossRef]

64. Kalinichenko, V.P.; Sharshak, V.K.; Ladan, E.P.; Illarionov, V.V.; Genev, E.D. Means of subsurface tillage with low driving resistance. Bull. Don State Tech. Univ. 2014, 14, 2. [CrossRef]

65. Matishov, G.G.; Kalinichenko, V.P.; Sharshakov, V.K.; Illarionov, V.V.; Ladan, E.P.; Genev, E.D.; Mishchenko, N.A.; Endovickii, A.P.; Chernenko, V.V.; Sukovatov, V.A.; et al. Method of Long-Term Productivity Management of Steppes Biogeosystem of Southern Russia. Available online: https:/ / new.fips.ru/Archive/PAT/2012FULL/2012.01.10/DOC/RUNWC1/000/000/002/438/293/ DOCUMENT.PDF (accessed on 6 July 2021).

66. Kalinichenko, V.P.; Sharshak, V.K.; Illarionov, V.V.; Ladan, E.P.; Genev, E.D.; Gromyko, E.V.; Zinchenko, V.E.; Balakay, G.T.; Radevich, E.V.; Balakay, N.I.; et al. Device for Loosening the Inner Layer of Soil. Available online: https:/ / new.fips.ru/Archive/P AT/2012FULL/2012.03.20/DOC/RUNWC2/000/000/002/444/874/DOCUMENT.PDF (accessed on 6 July 2021). 
67. Kalinichenko, V.P.; Sharshak, V.K.; Zinchenko, V.E.; Ladan, E.P.; Illarionov, V.V.; Genev, E.D.; Chernenko, V.V.; Endovitsky, A.P.; Il'in, V.B.; Larin, S.V.; et al. Device for Subsurface Rotational Loosening. Available online: https://new.fips.ru/Archive/PAT/201 2FULL/2012.07.10/DOC/RUNWC2/000/000/002/454/846/DOCUMENT.PDF (accessed on 6 July 2021).

68. Kalinitchenko, V.P. Device for Rotary Subsurface Tillage. Available online: https://new.fips.ru/Archive/PAT/2013FULL/2013.0 2.20/DOC/RUNWC2/000/000/002/475/005/DOCUMENT.PDF (accessed on 6 July 2021).

69. Kalinichenko, V.P.; Glinushkin, A.P.; Sokolov, M.S.; Budynkov, N.I.; Zinchenko, V.E.; Chernenko, V.V.; Kozyrev, S.G. The Method of Intra-Soil Introducing of Biological Product. Available online: https://new.fips.ru/ofpstorage/Doc/IZPM/RUNWC1/000/00 0/002/720/634/\%D0\%98\%D0\%97-02720634-00001/document.pdf (accessed on 6 July 2021).

70. North Caucasus State Zonal Machine Test Station, Act of verification of rotor mechanical drive of the intra-soil milling device. February the 18th 2008, Zernograd, Russia.

71. Sokolov, M.S.; Glinushkin, A.P.; Toropova, E.Y. Habitat functions of healthy soil—phyto-sanitary and social aspects. Agrochemistry 2015, 8, 81-94.

72. Kalinitchenko, V.P.; Glinushkin, A.P.; Sokolov, M.S.; Sharshak, V.K.; Ladan, E.P.; Minkina, T.M.; Zinchenko, V.E.; Chernenko, V.V.; Makarenkov, D.A.; Rykhlik, A.E.; et al. Nature-Based Technologies of Biogeosystem Technique. Agrochemistry 2020, 2, 61-68. [CrossRef]

73. Glazko, V.I.; Glazko, T.T. Conflicts of biosphere and agroecosystems. Int. J. Environ. Probl. 2015, 1, 4-16. [CrossRef]

74. Kalinitchenko, V.; Batukaev, A.; Zarmaev, A.; Startsev, V.; Chernenko, V.; Dikaev, Z.; Sushkova, S. Retem technique as the way to certainty of soil, hydrosphere, environment and climate. Geophys. Res. Abstr. 2016, 18, EGU2016-3419. 